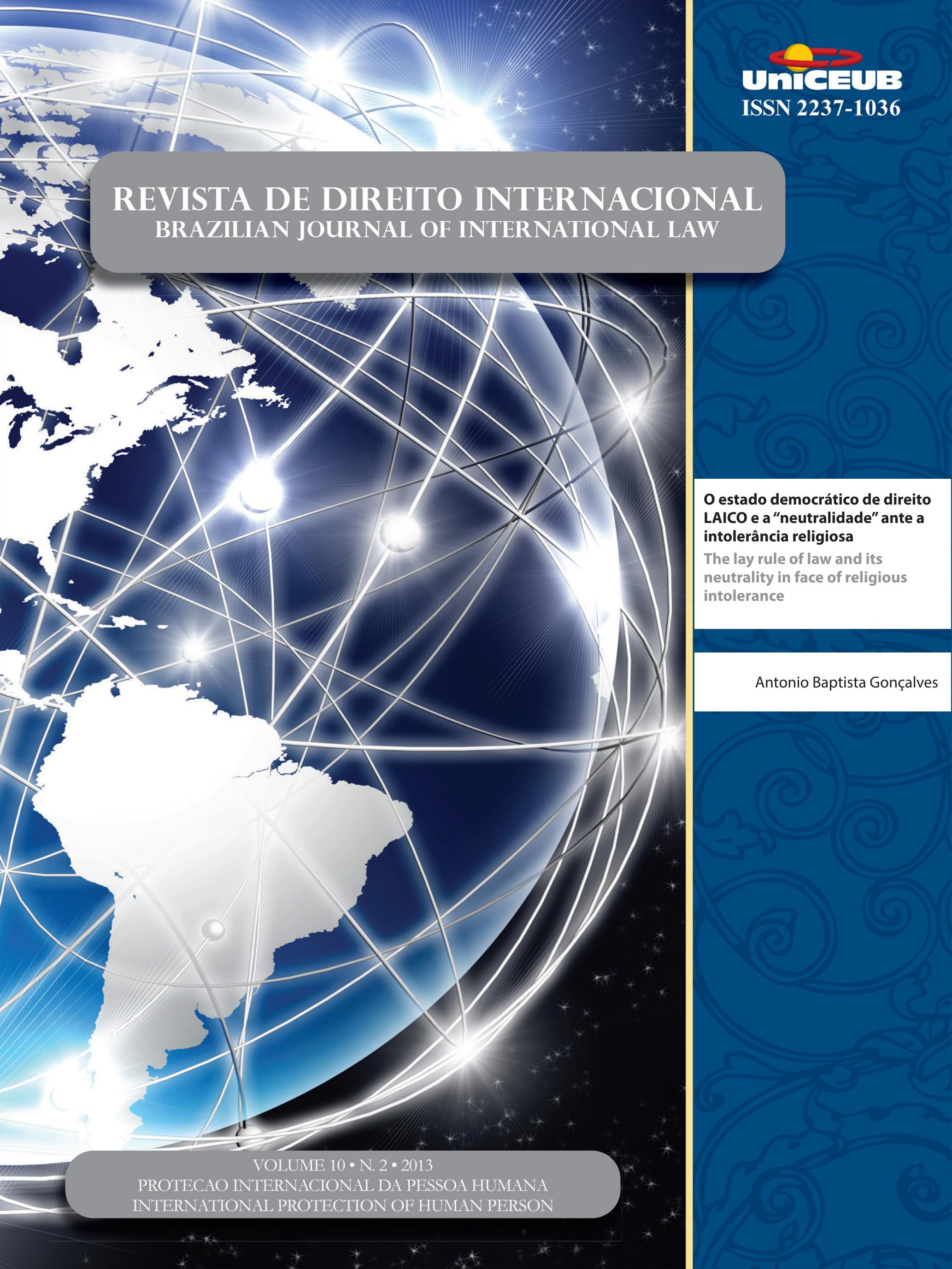




\section{Artigo Especial}

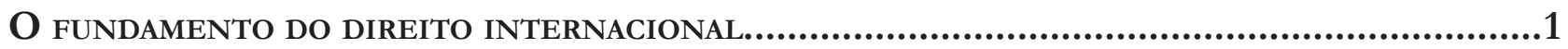
Alfred Verdross

\section{Proteção Internacional dos Direitos Humanos}

INDIGENOUS RIGHTS MOVEMENT: IS THE SAME NEEDED TO PREVENT CONTINUED HUMAN RIGHTS VIOLATIONS OF THE MENTALLY ILL

Liesel LeCates

O Discurso DAS DROGAS CONSTRUído PELO DIREITO INTERNACIONAL

Camila Soares Lippi

O ESTADO DEMOCRÁTICO DE DIREITO LAICO E A "NEUTRALIDADE" ANTE A INTOLERÂNCIA RELIGIOSA

Antonio Baptista Gonçalves

UM DiREITO SEM ESTADO? DiREITOS humanos E A FORMAÇÃo DE UM NOVO QUADRo NORMATIVO GLOBAL .87

Anderson Vichinkeski Teixeira e Rafael Köche

\section{Direito Humanitário}

The U.N. Standard Minimum Rules for the Treatment of Prisoners and North Korea: How North Korea is Violating these Rules with its Operation of the Yodok Concentration CAMP.

Tom Theodore Papain

U.S. Institutionalized Torture with Impunity: Examining Rape and Sexual Abuse in Custody Through the ICTY JurisprudenCE. 126 Allison Rogne 
Abduction, Torture, Interrogation: An Argument Against Extraordinary RendiTION

Kaitlyn E. Tucker

United States and European Union approaches to the death penalty: America SHOULD CONSIDER A NEW PERSPECTIVE 155 Katie R Hill

Tudo DE NOVO NO FRONT: MONUSCO, UMA NOVA ERA NAS PEACEKEEPING OPERATIONS? .169 Priscila Fett

A ADMINISTRAÇÃo DE TERRITÓRIOS OCUPADOS: INDETERMINAÇÃO DAS NORMAS DE DIREITO INTERNACIONAL HUMANITÁRIO?. 184 João Henrique Ribeiro Roriz, Fabia Fernandes Carvalho Veçoso e Lucas da Silva Tasquetto

THE (IN)APPLICABILITY OF THE STATUTE OF REFUGEES TO ENVIRONMENTALLY DISPLACED PERSONS 197 Maria Cláudia da Silva Antunes de Souza e Lucas de Melo Prado

\section{Sistema Interamericano de Direitos Humanos}

A contribuição da Comissão Interamericana de Direitos Humanos para o acesso À jus-

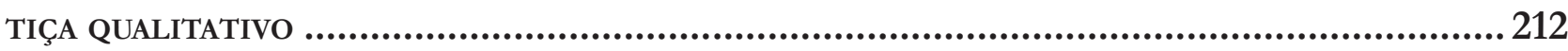
Márcio Antônio de Oliveira Filho, Ana Caroline Portes de Oliveira, Jéssica Galvão Chaves e Warlen Soares Teodoro

A executividade das sentenças da Corte Interamericana de Direitos Humanos no

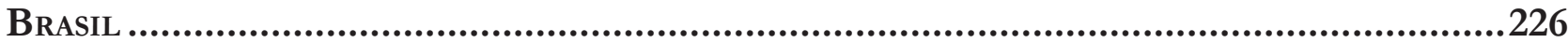

Augusto César Leite de Resende

A efetividade do ativismo jurídico transnacional no Sistema Interamericano de DiREITOS HuMANOS: UMA ANÁLISE A PARTIR DE CASOS CONTRA O BRASIL .................................238 Renata Mantovani de Lima e Lucélia de Sena Alves

O Processo e o Direito Coletivo no Sistema Interamericano de Direitos Humanos: UMA ANÁLISE COM BASE NA JURISPRUDÊNCIA INTERNACIONAL ...........................................250 Laercio Dias Franco Neto e Dafne Fernandez de Bastos 
CORTE INTERAMERICANA DE DIREITOS HUMANOS: OPINIÃo CONSULTIVA 4/84 - A MARGEM DE

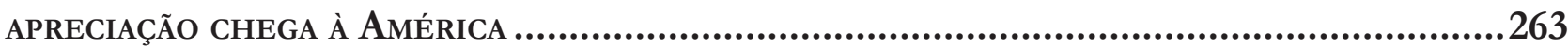

Paloma Morais Corrêa

A "PLENA" LIBERDADE DE EXPRESSÃo E OS DIREITOS HUMANOS: ANÁLISE DA JURISPRUDÊNCIA DA Corte InTeramericana de Direitos Humanos e o Julgamento da ADPF 130 281 Natália Paes Leme Machado

A proteção do meio ambiente no Sistema Interamericano de Direitos Humanos a parTIR DO DIREITO À EDUCAÇÃO.

Augusto César Leite de Resende

Parameters and procedures of the Inter-American System of Human Rights in CHILDREN'S RIGHTS VIOLATION LAWSUITS

Maria Guiomar da Cunha Frota e Pedro Alves Barbosa Neto

Poverty as a Violation of Human Rights: THE CASE OF STREET CHILDREN IN GUATEMALA AND BRAZIL

Paloma Morais Correa

\section{Proteção Internacional dos Direitos Humanos e o Direito Brasileiro}

A LEI N. 11.340/06 E SUAS REPERCuSSõES No CONTRATO INDIVIDUAL DE TRABALHo. Humberto Lima de Lucena Filho e Waldeny Pereira Filho

ORIENTAÇÃo SEXUAL E DISCRIMINAÇão NO AMBIENTE LABORAL

Glaucia Fernanda Oliveira Martins Batalha

NORMAS EDITORIAIS 


\title{
O estado democrático de direito LAICO e a "neutralidade" ante a intolerância religiosa
}

\section{The lay rule of law and its neutrality in face of religious intolerance*}

\author{
Antonio Baptista Gonçalves**
}

\section{Resumo}

Os Estados laicos são os responsáveis por implementarem a tolerância e as liberdades no âmbito interno do Estado Democrático de Direito. Contudo, o que se percebe na prática, é que o Estado somente é laico na proporção de sua própria intolerância. Assim, se questiona a neutralidade do Estado laico e, principalmente, o papel do Estado no cenário internacional da proteção das liberdades em conformidade com o sistema internacional de Direitos Humanos, desenvolvido pela Organização das Nações Unidas, ao qual os Estados laicos são signatários.

Palavras-chaves: Intolerância. Neutralidade. Estado laico.

\section{Abstract}

The secular states are responsible for implementing tolerance and freedoms within the internal democratic state. However, what is perceived in practice is that the state is secular only in proportion to its own intolerance. Thus, one questions the neutrality of the secular state, and especially the state's role in the international protection of freedoms in accordance with international human rights system developed by the United Nations to which the secular states are signatories.

Keywords: Intolerance. Neutrality. Secular State.

* Recebido em 16/07/2012 Aprovado em 25/01/2013

** Advogado. Membro da Associação Brasileira dos Constitucionalistas. Membro da Association Internationale de Droit Pénal. Doutor e Mestre em Filosofia do Direito - PUC/ SP. Especialista em International Criminal Law: Terrorism's New Wars and ICL's Responses Instituto Superiore Internazionale di Scienze Criminali. Especialista em Direitos Fundamentais pela Universidade de Coimbra. Especialista em Direito Penal Econômico Europeu pela Universidade de Coimbra. Pós-graduado em Direito Penal - Teoria dos Delitos - Universidade de Salamanca. Pós-graduado em Direito Penal Econômico da Fundação Getulio Vargas - FGV. Bacharel em Direito pela Universidade Presbiteriana Mackenzie. Email: antonio@antoniogoncalves.com

\section{INTRODUÇÃo}

O tema neutralidade na relação com a tolerância religiosa ganha cada vez mais importância na agenda do dia das discussões globais, dados os eventos recentes de demonstrações de intolerância dos Estados Democráticos de Direito, supostamente laicos.

De tal sorte, será necessária uma incursão do que vem a ser neutralidade e como esta se processa nos Estados, em especial os Democráticos, para, enfim, analisar o impacto da intolerância ante ao Estado Moderno e a neutralidade. 


\section{Conceito preliminar de neutralidade}

Aqui, oferecemos uma definição preliminar do que vem a ser neutralidade e levantaremos alguns aspectos a serem discutidos acerca do assunto, em especial, após a Segunda Guerra Mundial. Importante destacar que a discussão ainda será deveras incipiente e tem o condão apenas de suscitar mais questionamentos do que dirimi-los, tarefa que faremos ao longo do próprio texto.

Neutralidade é definida como a condição daquele que permanece neutro; condição de um país que não participa de uma guerra. ${ }^{1}$ Neutralidade, na acepção do Direito Internacional Público, exprime a posição de imparcialidade, imposta pela neutralidade declarada, o país neutro fica na obrigação de não intervir no conflito, de qualquer forma, devendo, por isso, abster-se da prática de qual ato que possa aproveitar um dos beligerantes em prejuízo do outro. Assim, a neutralidade, no sentido do Direito Internacional, não se presume mera indiferença. Revela-se a obrigação de não intervenção ou auxílio, sob qualquer pretexto, salvo para a paz, a favor ou contra quaisquer dos beligerantes. ${ }^{2}$

Neutralidade, portanto, significa a não tomada de posição de uma Nação sobre um tema em específico. No entanto, a grande reflexão a ser feita é: em tempos de globalização, é possível um Estado se manter completamente neutro sobre qualquer outro assunto que reverbere em outra Nação?

Assim, temos alguns exemplos: os eventos recentes da Primavera árabe, a queda do governo do Egito, a revolta popular na Líbia, os problemas enfrentados na Síria e no Iêmen, apenas para citar alguns exemplos que envolvem a democracia e o povo.

Pode-se afirmar que a Europa, os Estados Unidos, o Brasil ou qualquer outro Estado-nação se manteve neutro, de fato, nesses assuntos, ou o correto é afirmar que os Estados, em verdade, deixaram o próprio povo resolver o conflito no âmbito interno em um restaurar dos próprios princípios conformadores da Democracia? Ou, o objetivo foi não adquirir o espólio de um Estado em crise e sem governo? A neutralidade foi para legitimar o processo democrático, ou para proteger a si próprio de um eventual dispêndio econômico?

1 DICIONÁRIO Houaiss da língua portuguesa. Rio de Janeiro: Objetiva, 2009. p. 2014.

2 Neutralidade. Derivado do latim neutralis, de neuter (que fica indiferente), em sentido genérico quer significar o estado de neutro, ou seja, a situação daquele que se coloca indiferente ou fica imparcial diante da questão ou luta referida entre outros. Assim, é a situação de quem não tem ou não mostra qualquer interesse a respeito do que outros estão fazendo. SILVA, De Plácido e. Vocabulário jurídico. 28. ed. Rio de Janeiro: Forense, 2010. p. 950.
Ainda no tocante à neutralidade, se aliarmos os acontecimentos da última década em conflitos armados e terrorismo, como fica a questão da neutralidade com as medidas adotadas pelos países laicos em torno da intolerância religiosa?

Esse tema nos parece ser o emblemático na análise acerca do primado fundamental da neutralidade: a laicidade $^{3}$ do Estado Democrático de Direito. ${ }^{4}$

Se um Estado é laico, ${ }^{5}$ ele não poderá ser mais ou menos intolerante na medida de seus interesses. A liber-

3 A laicidade foi formada no século XIX a partir do adjetivo laï (leigo, aquele que não pertence ao clero). O termo deriva do grego Laos, que significa povo. Esse termo vai aparecer em 1871, quando será associado ao ensino público francês e seu surgimento será assinalado pelo Novo Dicionário de Pedagogia e de instrução primária, de autoria de Ferdinand Buisson, publicado em 1887. No verbete laicidade, contido nesse dicionário, Buisson nos informa que: a Revolução Francesa fez aparecer pela primeira vez com clareza a ideia de Estado laico, de Estado Neutro entre todos os cultos, independente de todos os clérigos, liberado de toda concepção teológica. "[...] a grande ideia, a noção fundamental do Estado laico, quer dizer, a delimitação profunda entre o temporal e o espiritual entrou nos costumes de maneira a não o mais sair". DOMINGOS, Marília de Franceschi Neto. Escola e laicidade: o modelo francês. Interações: cultura e comunidade, Uberlândia, v. 3, n. 4, p. 153-170, 2008. Ainda sobre o tema: "A laicidade é um dos princípios dos Estados Modernos, como por exemplo, o Brasil. Mas o tema carrega significados bem mais fortes do que o mero fato de ser um preceito. Atribui-se ao inicio das discussões sob o assunto ao Estado Francês, que em 1880 notadamente com leis escolares institucionaliza este princípio... A laicidade francesa deu-se através de uma construção histórica de mais de um século e hoje encontra-se difundida em diversos países, sem jamais ter suscitado tantos debates como naquele país, em especial no campo da Educação". DOMINGOS, Marília de Franceschi Neto. Escola e laicidade: o modelo francês. Interações: cultura e comunidade, Uberlândia, v. 3, n. 4, p. 153-170, 2008.

4 Carlos Ari Sundfeld identifica os elementos que determinam um Estado Democrático de Direito: “a) criado e regulado por uma Constituição; b) os agentes públicos fundamentais são eleitos e renovados periodicamente pelo povo e respondem pelo cumprimento de seus deveres; c) o poder político é exercido, em parte diretamente pelo povo, em parte por órgãos estatais independentes e harmônicos, que controlam uns aos outros; d) a lei produzida pelo Legislativo é necessariamente observada pelos demais Poderes; e) os cidadãos, sendo titulares de direitos, inclusive políticos e sociais, podem opô-los ao próprio Estado; f) o Estado tem o dever de atuar positivamente para gerar desenvolvimento e justiça social". SUNDFELD, Carlos Ari. Fundamentos de direito público. 4. ed. São Paulo: Malheiros, 1997, p. 56 e 57.

5 Sobre laico e laicidade: "Significa a separação entre Estado e as religiões. Tal sentido encontra a sua origem no contraste entre as palavras laico e religioso - é laico o que independe da religião. Logo, o Estado laico é o Estado separado das religiões. Isto é, é o Estado que decide, governa e promove interesses com base em critérios religiosos. Embora esta concepção mais específica se apresente a partir de um contraste, ela não se revela, essencialmente, um conflito, mas tão somente uma distinção, assinalando a fronteira que existe, ou que deveria existir entre o Estado e a religião". CASSAMANO, Marco Aurélio. Politica e religião: o estado laico e a liberdade religiosa à luz do constitucionalismo brasileiro. 2006. f. Tese (Doutorado na área de concentração de Direito, Estado e Sociedade)— Pontifícia Universidade Católica de São Paulo, São Paulo, 2006. p. 133. 
dade é do povo e cabe ao Estado assegurá-la e efetivá-la. Se os Estados pregam e preconizam a tolerância, não podem, na prática, ser intolerantes.

O Estado que não adota a religião de forma oficial deve ser neutro no que tange à questão religiosa, isto é, ser tolerante e professar e instituir as liberdades de acordo com os direitos fundamentais em consonância com o sistema internacional de Direitos Humanos desenvolvidos pós-Segunda Guerra Mundial.

O Estado Democrático de Direito, ao ser intolerante, promove e ocasiona o entrave de uma série de direitos que deveriam ser por ele instituídos, tais como: o desenvolvimento das liberdades, o neoconstitucionalismo, a laicidade, o pluralismo e a defesa da vida humana por meio da defesa da dignidade da pessoa humana.

Um Estado não pode ser um pouco neutro, assim como não pode ser igualmente um pouco laico. A laicidade não pode ser condicionada à proporção da própria intolerância do Estado. Isso não se coaduna com a neutralidade religiosa.

Ademais, a proteção da dignidade da pessoa humana também perpassa pela defesa das liberdades individuais. ${ }^{6}$ E sobre liberdades, ${ }^{7}$ podemos elencar: religiosa, expressão, consciência, circulação, opinião, sexo e raça, dentre outras.

De tal sorte que o mote fundamental, o fio condutor para o pleno exercício dessas liberdades, ${ }^{8}$ inclusive

6 “[...]. A liberdade, ao contrário, é colocada junto a outros direitos, tais como o direito à vida e à felicidade. [...] 'Liberdade' e 'igualdade' hoje não significam o mesmo que significavam nas páginas de Locke ou nas declarações do século XVIII: o seu conteúdo ampliou-se, tornou-se cada vez mais rico e denso; o seu significado fez-se cada vez mais pleno". BOBBIO, Norberto. O terceiro ausente. Tradução Daniela Versiani. Barueri: Manole, 2009. p. 82 e 87.

7 O conteúdo moderno da liberdade compreende os direitos de todos os homens de exercer suas atividades civis, intelectuais e morais; o direito de ir e vir; de não ser detido arbitrariamente; a inviolabilidade do domićlio; o direito de praticar qualquer religião; o direito de associar-se; o direito de petição; o direito de tomar parte na organização e no exercício do poder político; o direito de votar e ser votado; o direito à independência econômica etc. SILVA, José da. Liberdade, realidade política e eficácia da constituição. In: ROCHA, Maria Elizabeth Guimarães Teixeira; MEYER-PFLUG, Samantha Ribeiro. Lições de direito constitucional em homenagem ao professor Jorge Miranda. Rio de Janeiro: Forense, 2008. p. 137.

8 "A ordem prática ou ordem ética é a que se deve submeter às ações conscientes do ser humano. É esta a ordem da liberdade. Relativamente a ela, os homens são livres. Aqui, o homem é ator, cumpre-lhe conhecê-la, intervir nela, buscando por via de suas ações os fins que julgar autênticos. Nessa ordem do agir humano, os fins são livremente escolhidos pelos agentes, pois é regida por leis éticas e leis de um mundo de liberdade, onde a vontade do homem age". da dignidade da pessoa humana, é a execução, pelos indivíduos e, principalmente pelo Estado, da tolerância. Pois, se não for respeitado o direito da pluralidade de opiniões, de crenças, de ideias e de posições políticas, as liberdades, ${ }^{9}$ por conseguinte, estarão comprometidas.

Assim, o grande desafio continua sendo a neutralidade do Estado Democrático de Direito e a sua função primordial: efetivar e garantir as liberdades sem limitá-las ou relativizá-las.

No entanto, para a compreensão da neutralidade do Estado Democrático de Direito, entendemos ser necessário analisar uma etapa ainda anterior: a criação do Estado enquanto Nação, pois, a transição do período dos Impérios para o que temos e conhecemos hoje como Estado e Nação nos propiciará analisar como que a neutralidade se forma em conformidade com o conceito do próprio Estado.

\section{A IDENTIFicação de UM CONCEITO de ESTAdo NA ÉPOCA DOS IMPÉRIOS: UM COMPARATIVO COM A CONCEPÇÃO DE ESTADO-NAÇÃO E A CONTRO- VÉRSIA ACERCA DO CONCEITO DO QUE VEM A SER ESTADO}

Não é correto afirmar que não existiam Estados no período dos Impérios e nem mesmo anterior a eles, pois, ainda que de forma mais simples ou rudimentar, o Estado em sua concepção já existia. ${ }^{10}$

SILVA, José da. Liberdade, realidade política e eficácia da constituição. In: ROCHA, Maria Elizabeth Guimarães Teixeira; MEYERPFLUG, Samantha Ribeiro. Liçoes de direito constitucional em homenagem ao professor Jorge Miranda. Rio de Janeiro: Forense, 2008. p. 135 - 136. 9 "O significado tradicional de liberdade - pelo qual se falava de uma liberdade religiosa, ou de pensamento, ou de reunião, ou de associação, em sentido geral e específico, de uma liberdade pessoal - era aquele relacionado à faculdade de fazer ou não fazer determinadas coisas não impedidas por normas vinculantes; era a liberdade entendida como não-impedimento, ou liberdade negativa. A esfera da liberdade coincidia com a esfera dos comportamentos não regulados, e, portanto lícitos ou indiferentes. Montesquieu expressou muito bem o conceito quando afirmou que a liberdade consiste em fazer tudo o que as leis permitem". BOBBIO, Norberto. O Terceiro ausente. Tradução Daniela Versiani. Barueri: Manole, 2009. p. 88.

10 "É comum, entre os teóricos da política, o reconhecimento de que o Estado é uma figura teorética da Era Moderna. Os grupos arcaicos constituíam sistemas simples, identificados, em geral, por fatores totêmicos, cujo exemplo típico é a tribo. Os agrupamentos antigos que veem aumentada a sua complexidade estrutural pelo desenvolvimento da agricultura e pelo aparecimento dos mercados passam a ser identificados por outros fatores, o que nos permite falar em polis, regnum, respublica. A expressão 'Estado' só adquire um es- 
No entanto, para a análise de nosso trabalho, é necessário um corte epistemológico, portanto, o período ao qual devemos nos ater é o da formação do Estado-nação e, por conseguinte, o surgimento do nacionalismo.

Contudo, não podemos desenvolver o conceito de Estado-nação sem perpassar pela definição de Estado e, antes disso, por um período de transição entre o Império, ao conceito de nação-Estado, portanto, um momento ainda anterior ao de Estado-nação.

Então, o conceito moderno de Estado, ${ }^{11}$ apesar de ainda que rudimentarmente similar, é diferente daquele que poderíamos aplicar, em seu substrato, ao modelo de Estado da época do Império e, ainda, anterior a ele. ${ }^{12}$

Tercio Sampaio Ferraz Jr. acerca do surgimento do Estado:

Não se pode precisar exatamente quando nasce a forma Estado. É certo que as guerras do fim do séc. XV conduzem Espanha, França e Inglaterra a constituir-se em Estados. A Itália conhece uma transição, a dos principados, mas no séc. XVII, aí incluída a República de Veneza, já são constituídos

tatuto teórico na Era Moderna e é utilizada para designar formações bastante peculiares que, não obstante, parecem reproduzir caracteres comuns aos grupos políticos em geral. Essa aparência é que nos faz falar, às vezes e impropriamente, do 'Estado' grego, do 'Estado' romano, dos 'Estados' orientais”. FERRAZ JÚNIOR, Tercio Sampaio. Direito constitucional: liberdade de fumar, privacidade, estado, direitos humanos e outros temas. São Paulo: Manole, 2007. p. 413.

11 Nem todos entendem por Estado o mesmo conjunto de fatos. Para sermos exatos, precisemos o que denominamos como tal. A palavra Status, stato, estat (état), Estado, apareceu para marcar a passagem da organização política medieval para as formas estatais transcendentes à Land, a terra, à terre. Maquiavel e Jean Bodin usaram dela. Nela couberam todas as repúblicas e principados (tutti gli Stati). Compreende-se, pois, que houve adotado termo tão expressivo - lembrando "estabilidade", "peso" - e já o empregassem os Ingleses desde o século XIV, inclusive Shakespeare, e tardassem a precisar dele os alemães (século XVII). MIRANDA, Pontes de. Democracia, liberdade, igualdade: os três caminhos. Campinas: Bookseller, 2002. p. 28- 29.

12 De maneira geral, pode-se dizer que as organizações políticas da Antiguidade não chegam a se caracterizar como Estado, na medida em que as suas administrações eram dominadas pela indistinção da organização constitucional pela ausência de nomeação própria, pelo fato de ser a organização administrativa referida ao officia singularmente tomada. A presença do trabalho escravo permitia que boa parte dos serviços ditos hoje públicos fosse desempenhada por servos, libertos ou escravos. Estes não estavam a serviço da respublica, mas dos officia publicae (o senado, os cônsules, que tinham, cada qual, os seus servidores), regulados ou por normas comuns ou por regras sociais e religiosas. Em suma, em tempos modernos, dir-se-ia que as organizações antigas não conheciam a distinção entre administrar e governar. FERRAZ JÚNIOR, Tercio Sampaio. Direito constitucional: liberdade de fumar, privacidade, estado, direitos humanos e outros temas. São Paulo: Manole, 2007. p. 413 - 414. como Estados. Portugal, por causa de sua luta com os árabes e de sua afirmação política diante dos reinos espanhóis, assume precocemente o caráter estatal. ${ }^{13}$

Dalmo de Abreu Dallari:

A denominação Estado (do latim status = estar firme), significando situação permanente de convivência e ligada à sociedade política, aparece pela primeira vez em "O Príncipe" de MAQUIAVEL, escrito em 1513, passando a ser usada pelos italianos sempre ligada ao nome de uma cidade independente, como, por exemplo, stato di Firenze. Durante os séculos XVI e XVII a expressão foi sendo admitida em escritos franceses, ingleses e alemães. Na Espanha, até o século XVII, aplicava-se também a denominação de estados a grandes propriedades rurais de domínio particular, cujos proprietários tinham poder jurisdicional. De qualquer forma, é certo que o nome Estado, indicando uma sociedade política, só aparece no século XVI, e este é um dos argumentos para alguns autores não admitem a existência do Estado antes do século XVII. ${ }^{14}$

Em suma, após essa incursão do que vem a ser Estado, no Império é possível notar um modelo de Estado ainda pouco diferente do que conhecemos hoje. No entanto, ainda não se pode atrelar esse modelo ao de Estado-nação, por uma questão simples: ainda não havia a consonância entre a nação com o Estado. Como o Império anexava uma série de povos e cidades, não existia, portanto, uma uniformização da cultura, escrita, língua, uma única ideologia, em suma, uma identidade.

Anthony Giddens conceitua Estado: “Um Estado pode ser definido como uma organização política cujo domínio é territorialmente organizado e capaz de acionar os meios de violência para sustentar esse domínio". ${ }^{15}$

Assim, é possível se desenvolver o conceito de Estado.

Há uma grande concordância entre os cientistas quanto e como o Estado deve ser definido. Uma definição composta incluiria três elementos: primeiro, um Estado é um conjunto de instituições, definidas pelos próprios agentes do Estado. A instituição mais importante do Estado são os meios de violência e coerção; segundo, essas instituições encontram-se no centro do território geográfico limitado a que geralmente nos referimos como sociedade. De modo crucial, o Estado olha para dentro de si mesmo, no caso de sua sociedade nacional, e para

13 FERRAZ JÚNIOR, Tercio Sampaio. Direito constitucional: liberdade de fumar, privacidade, estado, direitos humanos e outros temas. São Paulo: Manole, 2007. p. 414.

14 DALLARI, Dalmo de Abreu. Elementos de teoria geral do estado. 19. ed. São Paulo: Saraiva, 1995. p. 43.

15 GIDDENS, Anthony. O estado-nação e a violência. Tradução Beatriz Guimarães. São Paulo: Universidade de São Paulo, 2001. p. 45. 
fora, no caso de sociedades mais amplas entre as quais ele precisa abrir seu caminho; seu comportamento em uma área, em geral, só pode ser explicado pelas atividades na outra; terceiro, o Estado monopoliza a criação das regras dentro do seu território. Isso tende à criação das regras dentro do seu território e à criação de uma cultura política comum, partilhada para todos os cidadãos. ${ }^{16}$

Porém, apesar de esta definição de Estado se aplicar aos Impérios, ainda que não em sua integralidade, existe uma justificativa para o estudo da neutralidade a partir do Estado-nação.

A razão de tal análise se calca no cenário político de uma pluralidade de Estados, o que não se observa quando da dominação dos povos por um único Império, como fora o caso dos persas, dos gregos, dos romanos e, mesmo no lado Oriental, com os otomanos, mais recentemente. Assim, a pluralidade de Estados, com os conflitos e disputas por seus próprios interesses em um cenário mais plural, é o tema central que propiciará o estudo da neutralidade.

\section{QUANDO A NAÇÃO AINDA NÃO SE MISTURA COM O ESTADO E O MOMENTO POSTERIOR: DA NA- ÇÃO-ESTADO AO SURGIMENTO DO ESTADO-NAÇÃO}

Eric J. Hobsbawm traça o perfil do mundo em um comparativo do ano de 1800 com o que temos atualmente:

\begin{abstract}
Não só o "mundo conhecido" era menor, mas também o mundo real, pelo menos em termos humanos. Já que para fins práticos não se dispunha de recenseamentos, todas as estimativas demográficas eram pura especulação, mas é evidente que a Terra abrigava somente uma fração da população de hoje; provavelmente não muito mais que um terço. Se as suposições mais comumente citadas não estiverem muito longe da realidade, a Ásia e a África tinham uma proporção um tanto maior de população mundial do que hoje; a Europa, com aproximadamente 187 milhões de habitantes em 1800 (contra cerca de 600 milhões hoje), tinha uma proporção um tanto menor, e as Américas tinham obviamente uma proporção muito menor ainda. Aproximadamente, dois de cada três seres humanos eram asiáticos em 1800; um de cada cinco, europeu, um de cada dez, africano, e um de cada 33 , americano ou da Oceania. ${ }^{17}$
\end{abstract}

16 DICIONÁRIO do pensamento social do século XX. Rio de Janeiro: Jorge Zahar, 1996. p. 257.

17 HOBSBAWM, Eric. A era das revoluções 1789-1848. Tradução Maria Tereza Teixeira e Marcos Pimentel. 25. ed. São Paulo: Paz e Terra, 2010. p. 28.
A Revolução Francesa ${ }^{18}$ teve o condão de modificar o cenário mundial em termos do conceito de Estado. ${ }^{19}$ Porém, como se tratou de uma revolução de um único País, ainda não era possível o desenvolvimento de um cenário plural e, quiçá do modelo de Estado-nação que conhecemos modernamente.

A modificação do cenário ocorreu no período entre 1848 e 1871, nos dizeres de Eric J. Hobsbawm:

Entre 1848 e 1871, ou mais precisamente durante
a década de 1860, três fatos ocorreram. Primeiro,
a expansão da industrialização produziu outras
potências essencialmente industriais e capitalistas
além da Inglaterra: os Estados Unidos, a Prússia
(Alemanha) e, muito antes disso, a França, tendo o
Japão se somado mais tarde. Segundo, o progresso
da industrialização fez que, de forma crescente,
a riqueza e a capacidade viessem a ser os fatores
decisivos no poderio internacional, diminuindo,
assim, a posição relativa da Rússia e da França e
aumentando a da Prússia (Alemanha). Terceiro,
a emergência como potências independentes de
dois Estados extraeuropeus, os Estados Unidos
(unidos sob o norte na Guerra Civil) e o Japão
(sistematicamente embarcando na "modernização"
da Restauração Meiji de 1868), criava pela primeira
vez a possibilidade de um conflito global entre
potências. ${ }^{20}$

Assumia-se, portanto, um caráter mais mundial, um cenário plural com a disputa econômica entre as potências. $^{21}$

18 Se a economia do mundo do século XIX foi formada principalmente sob a influência da Revolução Industrial Britânica, sua política e ideologia foram formadas fundamentalmente pela Revolução Francesa. "[...] A Revolução Francesa é assim a revolução do seu tempo, e não apenas uma, embora a mais proeminente, do seu tipo HOBSBAWM, Eric. A era das revoluções 1789-1848. Tradução Maria Tereza Teixeira e Marcos Pimentel. 25. ed. São Paulo: Paz e Terra, 2010. p. 97 e 100.

19 O mundo em 1789 era essencialmente rural e é impossível entendê-lo sem assimilar este fato fundamental. Em países como a Rússia, a Escandinávia ou os Bálcans, onde a cidade jamais se desenvolvera de forma acentuada, cerca de $90 \%$ a $97 \%$ da população era rural. “[...] A palavra 'urbano' é certamente ambígua. Ela inclui as duas cidades europeias que por volta de 1789 podem ser chamadas de genuinamente grandes segundo os nossos padrões - Londres, com cerca de 1 milhão de habitantes, e Paris, com meio milhão - e umas 20 outras com uma população de 100 mil ou mais. HOBSBAWM, Eric. A era das revoluções 1789-1848. Tradução Maria Tereza Teixeira e Marcos Pimentel. 25. ed. São Paulo: Paz e Terra, 2010. p. 32 - 33. 20 HOBSBAWM, Eric. J. A era do Capital 1848-1875. Tradução Luciano Costa Neto. 15. ed. São Paulo: Paz e Terra, 2011. p. 133.

21 "A estrutura formal internacional passou a divergir da estrutura real. A política internacional tornou-se política mundial, na qual pelo menos duas potências não europeias interviram de fato, embora isso não fosse evidente até o século XX. Mais ainda, esses países tornaram-se uma espécie de oligopólio de potências capitalistas industriais, exercendo um monopólio sobre o mundo, mas com- 
Philip Bobbitt aponta o surgimento das nações-Estado: "Dos Estados territoriais, aqueles que, como a Inglaterra, conseguiram sobreviver acabaram transformando-se em nações-Estado no século XIX". ${ }^{22} \mathrm{E}$ o que seria nação-Estado? A resposta é trazida por Philip Bobbitt: "A nação-Estado ${ }^{23}$ é um Estado que mobiliza uma nação - um grupo nacional étnico-cultural - para agir em benefício do Estado. Assim, pode contar com as receitas de toda a sociedade e o talento humano de toda a população". ${ }^{24}$

A nação-Estado se traduz em uma união, ainda que não tão sólida, entre o povo e o Estado, porque, em verdade, o segundo usa do primeiro para o seu desenvolvimento. Ainda não há uniformidade de ideias, mas sim, o uso do Estado do próprio povo.

O que temos de novo é a presença de uma unidade, de uma uniformização de cultura, escrita e linguagem dentro de um território ao qual se reconhece a figura de um ente superior, no caso, o Estado.

Nesse sentido John G. Stoessinger:

\begin{abstract}
O que constitui uma nação-estado em nosso tempo pode ser caracterizado do seguinte modo. Em primeiro lugar, é uma unidade política soberana. Em segundo lugar, é uma população que, entregue a uma dada identidade coletiva através de uma imagem comum do passado e do futuro, comunga de um maior ou menor grau de nacionalismo. E, finalmente, é uma população que habita um território definido, que reconhece um governo comum e que usualmente - conquanto nem sempre - exibe padrões linguísticos e culturais comuns. ${ }^{25}$
\end{abstract}

Logo, se percebe uma evolução em um comparativo com o modelo dos Impérios em que os territórios eram

petindo entre si, embora isso não fosse evidente até a era do imperialismo, depois do fim do nosso período". HOBSBAWM, Eric. J. A era do Capital 1848-1875. Tradução Luciano Costa Neto. 15. ed. São Paulo: Paz e Terra, 2011. p. 134.

22 BOBBITT, Philip. A guerra e a paz, na história moderna: o impacto dos grandes conflitos e da política na formação das nações. Tradução Cristiana Serra. Rio de Janeiro: Campus, 2003. p. 135.

23 "A nação-Estado não visa ao bem-estar do povo; pelo contrário, é legitimada pela criação de uma consciência nacional, pela fundição da nação ao Estado". BOBBIT'T, Philip. A guerra e a paz na história moderna: o impacto dos grandes conflitos e da política na formação das nações. Tradução Cristiana Serra. Rio de Janeiro: Campus, 2003. p. 163.

24 BOBBITT, Philip. A guerra e a paz na bistória moderna: o impacto dos grandes conflitos e da política na formação das nações. Tradução Cristiana Serra. Rio de Janeiro: Campus, 2003. p. 136.

25 STOESSINGER, John G. O poder das naçoes: a política internacional de nosso tempo. Tradução Jamir Martins. São Paulo: Cultrix, 1978. p. 31. agregados e as culturas miscigenadas, sem nenhuma unidade, e a impossibilidade de se criar um território único em termos linguísticos, culturais, de idioma etc.

Contudo, ainda não se pode vislumbrar uma unidade entre o Estado e o povo. Essa construção, iniciada na Revolução Francesa, teve o seu desenvolvimento definitivo com Napoleão Bonaparte no final do século XVIII e começo do XIX.

Assim, o que temos até o momento é a nação-Estado; logo, para chegarmos ao conceito de Estado-nação e suas implicações, cremos ser importante definir, primeiramente, o que vem a ser nação, para depois, analisar o conceito em relação ao Estado.

De Plácido e Silva:

Nação. Por sua origem etimológica, do latim natio, de natus (nascido), já se tem a ideia de que nação significa a reunião de pessoas, nascidas em um território dado, procedentes da mesma raça, falando o mesmo idioma, tendo os mesmos costumes e adotando a mesma religião, formando, assim, um povo, cujos elementos e características raciais e se mantêm unidos pelos hábitos, tradições, religião e língua. ${ }^{26}$

A nação ${ }^{27}$ é o substrato espiritual ou cultural em que se forma o Estado. Por isso, no mundo moderno, tendem a coincidir em múltiplos aspectos o Estado e a nação com o chamado Estado nacional. O Estado é considerado como a nação politicamente organizada, visto que tende a assumir limites nacionais. ${ }^{28}$

Para John G. Stoessinger, "A nação continua sendo a última instância no que se refere à vida do cidadão, não lhe restando nenhum outro recurso a autoridade superior". ${ }^{29}$

Eric J. Hobsbawm sinaliza a dificuldade de harmonia entre a nação e o Estado:

[...] continua intrigante o problema da relação dessa 'nação' vernácula, mesmo tão alargada, com o Estado, pois parece evidente que, em

26 SILVA, De Plácido e. Vocabulário jurídico. 28. ed. Rio de Janeiro: Forense, 2010. p. 937.

27 Eric J. Hobsbawm cita a tradicional definição de nação proposta por Josef Stalin: "Uma nação é uma comunidade desenvolvida e estável, com linguagem, território, vida econômica e caracterização psicológica manifestos em uma comunidade cultural". HOBSBAWM, Eric. Nações e nacionalismo desde 1780. Tradução Maria Celia Paoli e Anna Maria Quirino. São Paulo: Paz e Terra, 2011. p. 15.

28 FRANÇA, R. Limongi. Enciclopédia Saraiva de direito. São Paulo: Saraiva, 1977. v. 53. p. 497.

29 STOESSINGER, John G. O poder das nações: a política internacional de nosso tempo. Tradução Jamir Martins. São Paulo: Cultrix, 1978. p. 23. 
termos étnicos, linguísticos e outros, na maioria, os Estados, qualquer que fosse seu tamanho, não eram homogêneos e portanto não poderiam ser simplesmente equalizados com as nações. ${ }^{30}$

Então é possível perceber que havia nações e Estados, porém, ainda não se concebia, em sua maioria, a união entre os dois. E essa união somente foi percebida pouco mais tarde com Napoleão Bonaparte que agregou o povo ${ }^{31}$ para seus ideais em defesa de um Estado francês, isto é, o Estado-nação França, que seria o governo feito para e em conformidade com o povo, eis o que mais tarde se conheceria como o nacionalismo. ${ }^{32}$

30 HOBSBAWM, Eric. Naçoes e nacionalismo desde 1780. Tradução Maria Celia Paoli e Anna Maria Quirino. São Paulo: Paz e Terra, 2011. p. 29 e 30.

31 "Na prática, havia apenas três critérios que permitiam a um povo ser firmemente classificado como nação, sempre que fosse suficientemente grande para passar da entrada. O primeiro destes critérios era sua associação histórica com um Estado existente ou com um Estado de passado recente razoavelmente durável. Havia pouca controvérsia sobre a existência de um povo-nação inglês ou francês ou de um povo russo ou polonês, e também pouca controvérsia fora da Espanha sobre a existência de uma nação espanhola com características nacionais bem compreendidas. Pois uma vez dada a identificação da nação com o Estado, era natural que estrangeiros pressupusessem que o único povo em um país fosse aquele pertencente ao povo-Estado, um hábito que ainda irrita os escoceses. O segundo critério era dado pela existência de uma elite cultural longamente estabelecida, que possuísse um vernáculo administrativo e literário escrito. Isso era a base da exigência italiana e alemã para a existência de nações, embora os seus respectivos "povos" não tivessem um Estado único com o qual pudessem se identificar. Em ambos os casos, a identificação nacional era, em consequência, fortemente linguística, mesmo que (em nenhum dos dois casos) a língua nacional fosse falada diariamente por mais do que uma minoria - na Itália foi estimado que esta era $2,5 \%$ da população no momento da unificação - e que o resto falasse vários idiomas com frequências incompreensíveis mutuamente.

O terceiro critério, que infelizmente precisa ser dito, era dado por uma provada capacidade para a conquista. Não há nada como um povo imperial para tornar uma população consciente de sua existência coletiva como povo. HOBSBAWM, Eric. Nações e nacionalismo desde 1780. Tradução Maria Celia Paoli e Anna Maria Quirino. São Paulo: Paz e Terra, 2011, p. 49 e 50.

32 "De forma mais específica e concreta, o nacionalismo sustenta que o estado nacional, identificado como uma cultura nacional e comprometido com a sua proteção, é a unidade política natural. [...] O nacionalismo é um subproduto de condições predominantes no mundo moderno, quando a maioria das pessoas não mais vive em comunidades aldeãs fechadas, quando o trabalho é semântico, e não físico, e exige a capacidade de se comunicar em um idioma e uma escrita comuns, razoavelmente livres de contexto, quando a estrutura empregatícia muda rapidamente e não pode tolerar com facilidade uma divisão étnica do trabalho, e quando o contrato com grandes burocracias, tanto políticas quanto econômicas, e a dependência em relação a elas permeiam todos os aspectos da vida". DICIONÁRIO do pensamento social do século XX. Rio de Janeiro: Jorge Zahar, 1996. p. 508-510.
No entanto, Napoleão Bonaparte não teve o mérito exclusivo do nacionalismo, pois a grande mudança paradigmática foi a modernização e, principalmente, a alfabetização da população, para que fosse possível disseminar as ideias pretendidas e assimilar a língua, os costumes e a identidade do Estado francês para, então, usar do sentimento nacional a fim de unir a nação com o Estado.

Eric J. Hobsbawm destaca a importância da proliferação das escolas para o Estado-nação:

De fato, para os novos Estados-nação, essas instituições eram de importância crucial, pois apenas através delas a 'língua nacional' (geralmente construída antes por esforços privados) podia transformar-se na língua escrita e falada do povo, pelo menos para algumas finalidades. ${ }^{33}$

.E a consequência direta do Estado-nação e da cultura penetrando nas camadas do povo foi a modernização e a urbanização, como demonstra Eric J. Hobsbawm: "Na medida em que os Estados-nação eram formados, postos públicos e profissões da civilização progressista se multiplicavam, a educação escolar se tornava mais geral e, acima de tudo, a migração urbanizava populações rurais". ${ }^{34}$

Assim, com o uso do nacionalismo e da uniformização, houve aproximação maior entre o povo e os governantes, portanto, a outrora distancia entre o povo e a nobreza deixava de existir. De tal sorte que a população mais bem instruída participava do desenvolvimento do próprio Estado o que gerava sentimento de inclusão, formando, por conseguinte, uma unidade, uma união entre a nação e o Estado.

Para Anthony D. Smith:

No mundo moderno, somente uma forma de unidade política é reconhecida e permitida. Nós chamados esta forma de "Estado-nação". É fácil descobrir de que se trata. Estados-nação têm fronteiras, capitais, bandeiras, hinos, passaportes, moedas, paradas militares, museus nacionais, embaixadas e usualmente uma representação nas Nações Unidas. Eles também têm um governo para o território do Estado-nação, um sistema educacional úbico, um único sistema econômico e ocupacional, e usualmente um conjunto de direitos para todos os cidadãos, embora existam exceções. ${ }^{35}$

33 HOBSBAWM, Eric. J. A era do Capital 1848-1875. Tradução Luciano Costa Neto. 15. ed. São Paulo: Paz e Terra, 2011. p. 157.

34 HOBSBAWM, Eric. J. A era do Capital 1848-1875. Tradução Luciano Costa Neto. 15. ed. São Paulo: Paz e Terra, 2011. p. 158. 35 SMITH, Anthony D. Criação do estado e construção da nação. In: HALL, John A. (Org.). Os estados na história. Tradução Paulo Vaz, Almir Nascimento e Roberto Brandão. Rio de Janeiro: Imago, 1992. 
Como finaliza Eric J. Hobsbawm, o nacionalismo, portanto, parecia facilmente manejável dentro da estrutura do liberalismo burguês e compatível com ele. Um mundo de nações viria a ser, acreditava-se, um mundo liberal, e um mundo liberal seria feito de nações. ${ }^{36}$

O nacionalismo ${ }^{37}$ propiciava, portanto, a inclusão do povo nas questões estatais, o que ocasionava um elo entre a nação e o Estado, ${ }^{38}$ como já foi dito, no entanto, essa crescente participação popular é o que mais tarde se denominou de democracia.

No entanto, não podemos perder de vista o fato de que os Estados democráticos ainda não eram uma realidade, uma vez que ainda predomina a monarquia na realidade global.

p. 334.

36 HOBSBAWM, Eric. J. A era do Capital 1848-1875. Tradução Luciano Costa Neto. 15. ed. São Paulo: Paz e Terra, 2011. p. 160.

37 "Não confundir este conceito de nacionalismo com o que foi amplamente utilizado no final do século XIX. A própria palavra 'nacionalismo’ apareceu pela primeira vez em fins do século XIX, para descrever grupos ideólogos de direita na França e na Itália, que brandiam entusiasticamente a bandeira nacional contra os estrangeiros, os liberais e os socialistas, e a favor daquela expansão agressiva de seus próprios Estados, que viria a ser tão característica de tais movimentos". HOBSBAWM, Eric. A era dos impérios 1875-1914. Tradução Sieni Maria Campos e Yolanda Steidel de Toledo. 13. ed. São Paulo: Paz e Terra, 2011. p. 228.

38 “Os termos 'Estado-nação', 'Nação' e 'Nacionalismo' são, muitas vezes, caracteristicamente nivelados, usados na literatura das ciências sociais e da história como se fossem sinônimos. Mas devo fazer uma distinção entre eles. Por 'Nacionalismo' quero dizer um fenômeno que é basicamente psicológico - a adesão de indivíduos a um conjunto de símbolos e crenças enfatizado comunalmente entre membros de uma ordem política. Embora os sentimentos de nacionalismo frequentemente coincidam com a distribuição real da população dos Estados, e, enquanto aqueles que governam os Estados modernos normalmente procuram promover tais sentimentos sempre que possível há, sem dúvida, uma clara correspondência entre eles. Por 'Nação' refiro-me a uma coletividade existente dentro de um território claramente demarcado, sujeito a uma unidade administrativa, reflexivamente monitorada tanto pelo aparato de Estado interno como por aqueles de outros Estados. Tanto a nação quanto o nacionalismo são propriedades distintas dos Estados modernos, e no contexto de sua emergência original, assim como em outros locais, há mais do que uma conexão fortuita entre eles. Não pode haver nacionalismo, ao menos em sua forma moderna, sem a formação de nações. [...] O Estado-nação, que existe em um complexo de outros Estado-nação, é um conjunto de formas institucionais de governo, mantendo um monopólio administrativo sobre um território com fronteiras (limites) demarcados, seu domínio sendo sancionado por lei e por um controle direto dos meios internos e externos de violência”. GIDDENS, Anthony. O estado-nação e a violência. Tradução Beatriz Guimarães. São Paulo: Universidade de São Paulo, 2001. p. 140 a 145.

\section{DO ESTADO-NAÇÃO AO PERÍOdO EXPANSIONIS- TA: AS I E II GUERRAS MUNDIAIS}

Nesse novo cenário de Estado-nação com interesses econômicos e o aparecimento das potencias em termos globais, os Estados de menor tamanho e com limitações, em termos de desenvolvimento, também almejaram ingressar neste novo momento global.

Como consequência disso, o que se viu foi um período expansionista com o surgimento de novos Estados ${ }^{39}$ e nítida disputa por territórios.

Nesse cenário, temos o surgimento do período expansionista e que culminou com o que viria ser a Alemanha, a Itália, a Áustria e alguns outros Estados que se tornariam as potências do século XX.

E, após as revoluções do final do século XVIII, já era possível vislumbrar o conceito moderno de Estado, como mostra Eric J. Hobsbawm: ${ }^{40}$

O Estado moderno típico, que recebeu sua forma sistemática na era das revoluções francesas embora, de vários modos, ele tivesse sido antecipado pelos principados europeus que evoluíram a partir dos séculos XVI e XVII -, era uma novidade em muitos aspectos. Era definido como um território (de preferência, contínuo e inteiro) dominando a totalidade de seus habitantes; e estava separado de outros territórios semelhantes por fronteiras e limites claramente definidos. Politicamente, seu domínio e sua administração sobre os habitantes eram exercidos diretamente e não através de sistemas intermediários de dominação e de corporações autônomas. ${ }^{41}$

E o que permeou a realidade do final do século XIX para o principio do século XX foi a expansão, as alian-

39 "A construção de nações foi inevitavelmente um processo de expansão". HOBSBAWM, Eric. Nações e nacionalismo desde 1780. Tradução Maria Celia Paoli e Anna Maria Quirino. São Paulo: Paz e Terra, 2011. p. 44.

40 "Procurava, o mais possível, impor as mesmas leis e arranjos administrativos instituídos por todo o território, embora, depois da era das revoluções, estes não fossem mais as ideologias religiosas ou seculares. Crescentemente, esse Estado era obrigado a ouvir as opiniões dos indivíduos ou cidadãos, porque seu arranjo político lhes havia dado vOz - geralmente através de várias espécies de representação eleita - e/ou porque o Estado precisava do seu consentimento prático ou de sua atividade em outras coisas, como, por exemplo, contribuintes ou soldados potencialmente convocáveis". HOBSBAWM, Eric. Nações e nacionalismo desde 1780. Tradução Maria Celia Paoli e Anna Maria Quirino. São Paulo: Paz e Terra, 2011. p. 101. 41 HOBSBAWM, Eric. Nações e nacionalismo desde 1780. Tradução Maria Celia Paoli e Anna Maria Quirino. São Paulo: Paz e Terra, 2011. p.101. 
ças em busca de maior representatividade no cenário global, logo, a disputa passava a ser por poder. Com essa sede expansionista e a busca desenfreada pelo controle dos territórios não fica difícil imaginar que um conflito bélico era apenas uma questão de tempo. De tal sorte, a humanidade presenciou, em um período de 31 anos, de 1914 a 1945, a Primeira Guerra Mundial e a Segunda Guerra Mundial, com a disputa clara por poder, influência e territórios.

As guerras, não que se trate de um enredo inédito, ${ }^{42}$ porém, mostraram o viés do terror, como que o homem pode ser altamente destrutivo e que, se não fosse criado algum instrumento de controle, a própria espécie humana poderia padecer. ${ }^{43}$

\section{A ORGANIZAÇÃo DAS NAÇõES UNIDAS E A BUSCA PELA TOLERÂNCIA E A ASSUNÇÃO DAS LIBERDADES}

Desde o final da Segunda Guerra Mundial, as Nações se preocuparam em desenvolver instrumentos que protegessem a vida humana, pois a quantidade de vidas que foram perdidas em virtude das Guerras de 1914 a 1918 - I Guerra Mundial ${ }^{44}$ e de 1939 a 1945 - II Guerra

42 Antes das guerras mundiais, as disputas nos períodos dos Impérios já se destacavam pela crueldade e pela violência exacerbada.

43 Eric Hobsbawm: “[...] As décadas que vão da eclosão da Primeira Guerra Mundial aos resultados da Segunda foram uma Era de Catástrofe. Durante quarenta anos, ela foi de calamidade em calamidade. Houve ocasiões em que mesmo conservadores inteligentes não apostariam em sua sobrevivência. Ela foi abalada por duas guerras mundiais, seguidas por duas ondas de rebelião e revoluções globais que levaram ao poder um sistema que se dizia a alternativa historicamente predestinada para a sociedade capitalista e burguesa e que foi adotado, primeiro, em um sexto da superfície da Terra, e, após a Segunda Guerra Mundial, por um terço da população do globo. Os imensos impérios coloniais erguidos a Era do Império foram abalados e ruíram em pó. Toda a história do imperialismo moderno, tão firma e autoconfiante quando da morte da rainha Vitória, da Grã-Bretanha, não durara mais que o tempo de uma vida humana - digamos, a de Winston Churchill (1874-1965). HOBSBAWM, Eric. Era dos extremos. O breve século XX 1914-1991. Tradução Marcos Santarrita. 2. ed. São Paulo: Companhia das Letras, 1995. p. 16.

44 Calcula-se que morreram cerca de 9 milhões de civis e militares na I Guerra Mundial. A França teve 1,4 milhão de mortos, isto é, correspondente a $27 \%$ dos homens de 18 a 27 anos, ou $10 \%$ de sua população ativa masculina. A Alemanha teve 1,8 milhão de mortos, isto é, $9,8 \%$ de sua população ativa masculina; a Áustria-Hungria, 1 milhão, ou 9,5\%, respectivamente; a Itália, 530 mil, ou 6,2\%; a Inglaterra, 780 mil, ou 5,1\%; a Rússia, 1,7 milhão, ou 4,5\%; a Bélgica, 44 mil, ou 1,9\%; os EUA, 114 mil, ou 0,2\%; a Romênia contou com 600 mil mortos; a Sérvia, 400 mil; e a Turquia, 400 mil. GRANDE enciclopédia larousse
Mundial $^{45}$ ultrapassaram os 50 milhões. Um número expressivo de vidas perdidas em um espólio sem sentido decorrente de disputas por poder, exercício de dominação, busca por territórios e expansão forçada.

\section{Para Eric J. Hobsbawm:}

A Primeira Guerra Mundial reduziu a cacos o império dos Habsburgo e completou a desintegração do Império Otomano. Não fosse pela Revolução de Outubro, esse também teria sido o destino do império czar da Rússia, já muito enfraquecido, como foi o do império alemão, que perdeu tanto a Coroa quanto as colônias. A Segunda Guerra Mundial destruiu o potencial imperial da Alemanha, que alcançara breve realização com Adolf Hitler, e destruiu também os impérios coloniais da era imperial, grandes e pequenos: o britânico, francês, o japonês, o holandês, o português e o belga, assim como o que restava do espanhol. ${ }^{46}$

De tal sorte que a banalização da vida humana, em especial, com a Segunda Guerra Mundial, fez com que as Nações desenvolvessem um elemento, um organismo transnacional, que fosse responsável por criar diretrizes de condutas positivas e protetivas a serem seguidas pelas Nações signatárias. Nascia, em 26 de junho de 1945, em São Francisco, a Organização das Nações Unidas ONU, órgão que iria representar os 51 países signatários e proteger os cidadãos, suas relações, liberdades etc.

O foco, isto é, o objetivo central já fora estabelecido no Preâmbulo da Carta das Organizações Unidas. ${ }^{47}$

O marco fundamental dos direitos humanos, sem dúvida é a Declaração Universal dos Direitos do Homem, cuja aprovação ocorreu em 10 de dezembro de 1948, na Assembleia Geral das Nações Unidas. Contu-

cultural. São Paulo: Nova Cultural, 1998. v. 12. p. 2859.

45 As estimativas avaliam entre 40 a 52 milhões os mortos, entre os quais 7 milhões de deportados para a Alemanha, por motivos raciais e políticos. GRANDE enciclopédia larousse cultural. São Paulo: Nova Cultural, 1998. v. 12. p. 2863.

46 HOBSBAWM, Eric. Globalização, democracia e terrorismo. Tradução José Viegas. São Paulo: Companhia das Letras, 2007. p. 78.

47 "Nós, os povos das Nações Unidas, resolvidos a preservar as gerações vindouras do flagelo da guerra, que por duas vezes no espaço de nossa vida trouxe sofrimentos indizíveis a humanidade, e resolvidos a reafirmar a fé nos direitos fundamentais do homem, na dignidade e no valor do ser humano, na igualdade de direitos dos homens e das mulheres, assim como das nações grandes e pequenas, resolvidos também a estabelecer condições sob as quais a justiça e o respeito às obrigações decorrentes de tratados e de outras fontes de direito internacional possam ser mantidos e a promover o progresso social e melhores condições de vida dentro de uma liberdade mais ampla". DALLARI, Dalmo de Abreu. In: VIEIRA, Oscar Vilhena (Coord.). Direitos humanos, estados de direito e a construção da paz. São Paulo: Quartier Latin, 2005. p. 42. 
do, não podemos renegar o passado que impulsionou e motivou o surgimento dos Direitos Humanos que se concretizaram, de fato, pós-Segunda Guerra Mundial.

Para tanto, uma série de Tratados, Convenções e Pactos $^{48}$ foram desenvolvidos a fim de compromissar seus signatários a assegurar no âmbito interno e externo as liberdades entre os povos.

Ademais, após ratificarem as Convenções, Tratados ou Pactos, os Estados deveriam desenvolver em seu ordenamento jurídico instrumentos compatíveis com as premissas dos Direitos Humanos. Assim, os Estados criaram um sistema que privilegiava uma sociedade pluralista, aberta, que tem por objetivo assegurar a liberdade de pensamento, religião, crença, credo, expressão e consciência.

48 Declaração Francesa de Direitos do Homem, por meio do seu artigo 10; Carta das Nações Unidas, de 26 de junho de 1945; Preâmbulo da Declaração Universal dos Direitos do Homem, bem como o seu artigo $2^{\circ}$; Convenção Europeia dos Direitos do Homem, firmada em Roma, em 4 de novembro de 1950, por meio dos artigos 14, 18 e 26; Declaração sobre a Prevenção e Punição do Crime de Genocídio; Carta Encíclica PACEM IN TERRIS, editada pelo Vaticano, em 11 de abril de 1963; na sequência, o Vaticano emitiu, em 1965, a Declaração DIGNITATIS HUMANAE; artigo $4^{\circ}$ da Convenção Relativa ao Estatuto dos Refugiados; no mesmo sentido, a proteção à pratica religiosa em relação aos apátridas, conforme os artigos $3^{\circ}$ e $4^{\circ}$ da Convenção relativa aos Apátridas; em 1965, um novo marco histórico com a criação da Convenção Internacional sobre a Eliminação de Todas as Formas de Discriminação Racial; na mesma esteira temos o Pacto Internacional sobre Direitos Civis e Políticos, de 1966; ainda em 1966 tivemos o Pacto Internacional Sobre Direitos Econômicos, Sociais e Culturais e a questão da liberdade religiosa está presente no artigo 13; em 1979, a Convenção sobre a Eliminação de Todas as Formas de Discriminação Contra as Mulheres; em 1980, o então Papa João Paulo II emitiu uma mensagem aos países signatários do Ato final de Helsinque; e, em 1981, a ONU emitiu a mais importante Declaração sobre o assunto religião: a Declaração sobre a Eliminação de Todas as Formas de Intolerância e Discriminação Baseadas em Religião ou Crença; em $1^{\circ}$ de janeiro de 1988, o Papa João Paulo II emite uma mensagem por ocasião da celebração do XXI dia mundial da paz; em 1989, a ONU edita a Convenção Sobre os Direitos da Criança, e sobre liberdade religiosa é importante destacar o artigo 14. Em 1992 tivemos a importante Declaração Sobre os Direitos das Pessoas Pertencentes a Minorias Nacionais ou Étnicas, Religiosas e Linguísticas; em 1994, foi editado o Conselho da Liga dos Estados Árabes, isto é, a Carta Árabe de Direitos Humanos; em 1993 um novo passo para a ratificação dos direitos humanos, com a Declaração e Programa de Ação de Viena por meio da Conferência Mundial sobre Direitos Humanos, realizada em Viena entre os dias 14 e 25 de junho; em 2005, a Declaração Universal da Laicidade no século XXI; e, recentemente, a União Europeia, em 30 de março de 2010, criou o próprio regramento de direitos humanos mediante a Carta dos Direitos Fundamentais da União Europeia. A liberdade religiosa também foi mencionada no capítulo Liberdade de pensamento, de consciência e de religião, além de uma menção expressa ao respeito à diversidade religiosa no artigo 22.
Então, nesse novo cenário, os Estados desenvolveram importantes mecanismos de combate contra a intolerância e a violência, física, moral ou psicológica dela advinda.

\section{A organização das Nações Unidas e a QUESTÃO DA SOBERANIA DOS ESTADOS}

Com a criação da Organização das Nações Unidas, em 1945, o que se viu foi a edificação de um sistema de Direitos Humanos, o qual valoriza a proteção da dignidade da pessoa humana.

Assim, firmou-se um conjunto amplo de proteções que passam pela garantia das liberdades, inclusive a religiosa.

De tal sorte que, portanto, criou-se, em consonância com a vontade e a livre manifestação dos Estados aderentes, um Estado representativo aos quais os demais deveriam, em ratificando seus Pactos, Convenções, Tratados e demais instrumentos, respeitar e implementar tais medidas em seu cenário nacional.

Com a criação da Organização das Nações Unidas, a questão das potências e das disputas entre Estados ganhou novo capítulo, pois, agora, havia além das disputas econômicas, as pressões para a consolidação da proteção ao ser humano.

O resultado foi o debate se, com a criação da Organização das Nações Unidas, os Estados teriam seus "poderes" limitados. Instaurava-se, portanto, discussão em torno de soberania. E, uma vez mais o desenvolvimento de um instrumento tão importante e debatido no cenário global atual foi construído e desenvolvido em decorrência direta da Revolução Francesa, pois a ideia moderna de soberania do Estado é desenvolvida no art. $3^{\circ}$ da Declaração dos Direitos do Homem e do Cidadão de $1789 .^{49}$

No entanto, o próprio diploma gerou consequências na França, em relação à monarquia. Assim, a questão da soberania também deve ser entendida em torno do contexto histórico da Revolução como relata Fábio

49 "Art. $3^{\circ} \mathrm{O}$ princípio de toda soberania reside essencialmente na Nação. Nenhuma corporação, nenhum indivíduo pode exercer autoridade que dela não emane expressamente." COMPARATO, Fábio Konder. A afirmação bistórica dos direitos bumanos. 3. ed. São Paulo: Saraiva, 2003. p. 154. 
Konder Comparato: ${ }^{50}$ "O grande problema político do movimento revolucionário francês foi, exatamente, o de encontrar um outro titular da soberania, ou poder supremo, em substituição ao monarca". ${ }^{51}$

Christopher W. Morris destaca a soberania no Estado moderno:

Os Estados são 'soberanos' em seus territórios e reivindicam o monopólio do uso de força legítima dentro desse espaço. Isso é sustentado para diferenciar os Estados da Máfia ou de corporações multinacionais. Dados o seu poder e autoridade, as instituições estatais oferecem a muitos os meios de realizarem suas maiores ambições e sonhos. Não é de se estranhar a enormidade dos crimes associados aos Estados modernos. ${ }^{52}$

Exatamente na pretensão de limitar esse poder de concretizar o dano ao ser humano, que os próprios Estados decidiram limitar, no plano internacional, sua soberania em favorecimento à Organização das Nações Unidas, um órgão supranacional com efetividade garantida pelos Estados-membros.

No entanto, para compreender como se relaciona a Organização das Nações Unidas com o combate à intolerância, e como que esta se processa nos Estados laicos, importante aprofundar um pouco mais o tema da soberania.

\subsection{Conceito de soberania}

A França se notabilizou por desenvolver importantes construtos para o conceito de Estado e, sobre so-

50 "A ideia de monarquia absoluta, combatida por todos os pensadores do "século das luzes", tornou-se inaceitável para a nova classe ascendente a burguesia. Tinha esta, de fato, sólidos argumentos para retomar o movimento histórico em favor da limitação de poderes dos governantes, iniciados na Baixa Idade Média com a Magna Carta e seguido na Inglaterra pela Petition of Rights de 1628, o Habeas Corpus Act e o Bill of Rights. Não foi, aliás, por outra razão que Voltaire e Montesquieu sempre apresentaram a Inglaterra como o exemplo a ser seguido na França. Acontece que essa sequência histórica de atos de limitação de poder supunha, logicamente, a manutenção de um centro de poder a ser limitado, o qual, no caso da França, era tradicionalmente o rei. A partir do momento em que esse centro de poder político desaparecia, ou se encontrava seriamente enfraquecido, desequilibrava-se todo o edifício político. Dos três estamentos que compunham oficialmente a sociedade francesa, o clero e a nobreza não tinham, naquele momento histórico, a menor legitimidade para reivindicar para si a soberania, porque continuavam apegados a privilégios que oprimiam o povo humilde e restringiam a liberdade econômica dos burgueses". COMPARATO, Fábio Konder. A afirmação bistórica dos direitos humanos. 3. ed. São Paulo: Saraiva, 2003. p. 137.

51 COMPARATO, Fábio Konder. A afirmação bistórica dos direitos bumanos. 3. ed. São Paulo: Saraiva, 2003. p. 137.

52 MORRIS, Christopher W. Um ensaio sobre o estado moderno. Tradução Sylmara Beletti. São Paulo: Landy, 2005. p. 33 e 34. berania não foi diferente. Afinal, foi um francês, Jean Bodin, ${ }^{53}$ o primeiro autor ${ }^{54}$ a sistematizar o tema ${ }^{55}$ por meio de sua obra Os Seis Liuros da República, datada de 1576 e, assim, conceituar soberania: ${ }^{56}$

Soberania é o poder perpétuo de um Estado, que os latinos denominam maiestas; os gregos akra exousi, kurion arché e kurion politeuma; e os italianos segnioria, um termo usado tanto por pessoas privadas quanto por aqueles que tem poder total do Estado, enquanto os hebreus chamam de tomechet shévet que é o poder mais alto de comando. ${ }^{57}$

53 A primeira obra teórica a desenvolver o conceito de soberania foi Les Six Livres de la République, de Jean Bodin, havendo inúmeras fontes que apontam o ano de 1576 como o do aparecimento dessa obra. A leitura dos seis livros, que contêm apreciações e conclusões de caráter teórico, ao lado de fartas referências a ocorrências históricas citadas em apoio da teoria, deixa entrever que Bodin tomou como padrão, sobretudo, a situação da França, fazendo a constatação e a justificação dos costumes e complementando-as com apreciações que não são mais do que a revelação de sua própria concepção do que haveria de ser a autoridade real. Inicia-se o Livro I com a conceituação da República, como um direito de governo de muitas famílias e do que lhes é comum, com um poder soberano. O Capítulo VIII do Livro I é totalmente dedicado ao esclarecimento do conceito de soberania. Diz Bodin: "É necessário formular a definição de soberania, porque não há qualquer jurisconsulto, nem filósofo político, que a tenha definido e, no entanto, é o ponto principal e o mais necessário de ser entendido no Trabalho da República". Esclarece então que a "[...] soberania é o poder absoluto e perpétuo de uma República, palavra que se usa tanto em relação aos particulares quanto em relação aos que manipulam todos os negócios de estado de uma República”. DALLARI, Dalmo de Abreu. Elementos de teoria geral do estado. 19. ed. São Paulo: Saraiva, 1995. p. 67.

54 Temos, também contribuição igualmente preciosa de F. H. Hinsley acerca da visão de Jean Bodin ao inaugurar a visão de Direito Internacional: "En la obra de Bodin, de la republique (1577) por fin lós dos cabos se unen, produciendo la doctrina de la soberania en relación con la estructura interna de la comunidad politica y, por lo que toca a las relaciones entre comunidades, el reconocimiento de que la largamente establecida división romana del derecho en ius naturale, ius gentium y ius civile no pudiendo proporcionar un derecho público para las relaciones entre Estados independientes, era menester una nueva categoría de derecho: el derecho internacional'. HINSLEY, F. H. El concepto de soberania. Tradução Fernando Morera e Angel Alandí. Barcelona: Labor, 1972. p. 154 e 155.

55 Maquiavel e Bodin, por certo ângulo, viam na soberania um poder absoluto, de aparência ilimitada. BONAVIDES, Paulo. Teoria geral do estado. 8. ed. São Paulo: Malheiros, 2010. p. 38.

56 Não podemos deixar de ressaltar que a obra de Jean Bodin data do final do século XVI, logo, todo o modelo de Estado moderno ainda não existia, logo, sua visão de soberania se aplicava aos principados e, em especial, a Monarquia, o poder soberano do rei. Sobre o tema: A ideia de grandeza, majestade e sacralidade da soberania coroava a cabeça do príncipe e levantava as colunas de sustentação do Estado Moderno, que era o Estado da soberania ou do soberano, antes de ser Estado da Nação ou do povo. BONAVIDES, Paulo. Teoria geral do estado. 8. ed. São Paulo: Malheiros, 2010. p. 36.

57 Definição em BERARDO, Telma. Soberania e direitos humanos: reconceituação com base na dignidade da pessoa humana. 2003. f. Tese (Mestrado na área de concentração de Direito Constitucional)_Pontifícia Universidade Católica, São Paulo, 2003. p. 30. 
John G. Stoessinger acerca da visão de soberania desenvolvida no século XVI:

\begin{abstract}
Essa imagem política universal tem dois aspectos principais. Em primeiro lugar, o homem dotou a nação-Estado de uma qualidade que ela não partilha com nenhuma outra associação humana - o atributo de soberania. Aliás, não é mera coincidência que a teoria da soberania fosse primeiro formulada no século dezesseis, numa ocasião em que o sistema das nações-estado estava em vias de emergir do universalismo do mundo medieval. ${ }^{58}$.
\end{abstract}

Tercio Sampaio Ferraz Jr. afirma que a soberania já era conhecida na Idade Média:

\begin{abstract}
A Soberania - como poder/direito do soberano, já existia desde a Idade Média. Sua raiz social estava na relação direta e concreta entre o soberano e o súdito por meio dos mecanismos de apossamento da terra.

Por isso, até hoje soberania e territorialidade são conceitos próximos. Ora, a partir do Renascimento, o crescimento da atividade mercantil, o intercâmbio com o Oriente, as Cruzadas, as grandes descobertas afetam essa relação extremamente concreta do senhor sobre a terra e sobre os que nela vivem. ${ }^{59}$
\end{abstract}

Thomas Hobbes, ${ }^{60}$ no século XVII, em sua obra Leviatã, menciona, na introdução, seu conceito de soberania:

[...] pela arte é criado aquele grande Leviatã a que se chama Estado, ou Cidade (em latim Civitas), que não é senão um homem artificial, embora de maior estrutura e força que o homem natural, para cuja proteção e defesa foi projetado. E no qual a soberania é uma alma artificial, pois dá vida e movimento ao corpo inteiro. ${ }^{61}$

O que se pode perceber é o desenvolvimento de um importante instrumento em nossos dias: a instituição das primeiras linhas do que vem a ser hoje o Direito Internacional, pois, nessa seara, igualmente, temos a re-

58 STOESSINGER, John G. Opoder das nações: a política internacional de nosso tempo. Tradução Jamir Martins. São Paulo: Cultrix, 1978. p. 23. 59 FERRAZ JÚNIOR, Tercio Sampaio. Direito constitucional: liberdade de fumar, privacidade, estado, direitos humanos e outros temas. São Paulo: Manole, 2007. p. 421.

60 "“...] O poder soberano como algo que constitui a comunidade política e garante as relações sociais da propriedade. Foi isso que Hobbes percebeu e expôs com genialidade. É a clássica figura do Leviathan. Ao descrevê-lo Hobbes fala dele como um homem artificial, que faz todas as leis, mas não se submete a nenhuma delas, que não é igual nem desigual em relação aos súditos, apenas é diferente, é um outro, caracterizado pelo direito de ditar as leis e pela força de fazê-las cumprir" FERRAZ JÚNIOR, Tercio Sampaio. Direito constitucional: liberdade de fumar, privacidade, estado, direitos humanos e outros temas. São Paulo: Manole, 2007. 421.

61 HOBBES, Thomas. Leviatã. São Paulo: Nova Cultural, 1999. (Os Pensadores).p. 4. lação dos Estados no âmbito interno e externo, bem como as questões modernas envolvendo a soberania.

Dalmo de Abreu Dallari destaca a importância do tema para o Estado Moderno:

O que se verifica é que o conceito de soberania é uma das bases da idéia de Estado Moderno, tendo sido de excepcional importância para que este se definisse, exercendo grande influência prática nos últimos séculos, sendo ainda uma característica fundamental do Estado. ${ }^{62}$

Assim, ofertamos o nosso conceito de soberania. Soberania, portanto, significa a fortificação do Estado como um ente soberano, isto é, que nas questões atinentes a seu povo e ao modo de resolver os problemas internos, nenhum outro Estado poderá se intrometer, criticar ou intervir, pois o poder decisório cabe exclusivamente ao Estado, pois este é soberano. Esse conceito se aplica no âmbito interno em relação aos demais Estados.

\section{Para Lucas E. Barreiros:}

Cada Nación que se gobierna a si misma, bajo cualquier forma, y que no depende de ninguna outra, es un Estado soberano. [...] La libertad de una Nación no resultaría completa si otras naciones se tomaran la libertad de inspeccionar y controlar su conducta; una presunción que sería contraria al derecho natural, que declara a cada Nación libre e Independiente de todas las otras naciones. ${ }^{63}$

Agora, no cenário externo, se todos os Estados são soberanos e ninguém pode intervir em sua soberania, logo podemos afirmar que todos são iguais entre si e que, portanto, existe uma paridade de relações. ${ }^{64}$ Podemos concluir que o Estado moderno tem duas soberanias: uma interna, absoluta e outra externa, realtiva, uma vez que todos os Estados tem uma paridade no plano internacional, os Estados somente se obrigam entre si por mútuo consentimento. E aos conceitos desenvol-

62 DALLARI, Dalmo de Abreu. Elementos de teoria geral do estado. 19. ed. São Paulo: Saraiva, 1995. p. 63.

63 EMILIANO BARREIROS, Lucas. El derecho internacional contemporáneo y el problema de la soberanía: un intento de reconciliación. In: PINTO, Mónica. (Org.). Las fuentes del derecho internacional en la era de la globalización. Buenos Aires: Eudeba, 2009. p. 41. 64 "En la medida en que las naciones son libres, independientes e iguales, y en la medida en que cada una de ellas tiene el derecho de decidir en su conciencia ló que debe hacer para satisfacer sus obligaciones, el efecto de esto es producir, al menos ante el mundo, una perfecta igualdad de derechos entre las Naciones en la conducción de sus asuntos y en las prosecución de sus políticas". EMILIANO BARREIROS, Lucas. El derecho internacional contemporáneo y el problema de la soberanía: un intento de reconciliación. In: PINTO, Mónica. (Org.). Las fuentes del derecho internacional en la era de la globalización. Buenos Aires: Eudeba, 2009. p. 42. 
vidos acerca da soberania, sua ilimitabilidade, incondicionalidade e independência ${ }^{65}$ é que, em grande parte, ocasionarão os problemas no século XX - leiam-se Guerras Mundiais - e, enseja-se, assim, uma reformulação do conceito.

\subsection{A fortificação do papel do estado $x$ a conten- ção das mazelas ocasionadas pelo excesso de poder}

O Estado, em sua concepção moderna, ganhou força, representatividade e independência. Como mostramos, essa evolução foi decorrente do avanço do próprio papel do Estado na História. E, a Revolução Francesa pavimentou o caminho para a consolidação do Estado, pois se até então o que se via eram monarquias e a Igreja atuando em beneficio próprio, e a nobreza extraindo o máximo possível de riquezas, tudo começou a mudar com a Revolução e com a Independência dos Estados Unidos.

Somado a isso, temos de acrescer o nacionalismo e as revoluções industriais que fizeram os Estados prosperarem e se desenvolverem em um cenário mais globalizado, assim, tornando-se potencias.

O resultado foi a união de interesses entre o Estado e seus governantes com o povo que passou a ser incluído no processo de governo. Com a expansão dos territórios e a busca por influência, o que se viu de 1848 até 1914 foi o anseio dos Estados por poder e influência e, ao mesmo tempo, a consolidação da independência de seu território e de seu povo em relação aos demais

65 Dalmo de Abreu Dallari complementa: "Quanto às características da soberania, praticamente a totalidade dos estudiosos a reconhece como uma, indivisivel, inalienável e imprescritivel. Ela é uma porque não se admite num mesmo Estado a convivência de duas soberanias. Seja ela poder incontrastável, ou poder de decisão em última instância sobre a atributividade das normas, é sempre poder superior a todos os demais que existam no Estado, não sendo concebível a convivência de mais de um poder superior no mesmo âmbito. É indivisivel porque, além das razões que impõem sua unidade, ela se aplica à universalidade dos fatos ocorridos no Estado, sendo inadmissível, por isso mesmo, a existência de várias partes separadas da mesma soberania. Não se deve confundir a teoria da divisão do poder, de que mais adiante se tratará pormenorizadamente, com uma forma de divisão da soberania, pois a chamada divisão do poder é, na verdade, uma distribuição de funções. A soberania é inalienável, pois aquele que a detém desaparece quando ficar sem ela, seja o povo, a nação, ou o Estado. Finalmente, é imprescritivel porque jamais seria verdadeiramente superior se tivesse prazo certo de duração. Todo poder soberano aspira a existir permanentemente e só desaparece quando forçado por uma vontade superior". DALLARI, Dalmo de Abreu. Elementos de teoria geral do estado. 19. ed. São Paulo: Saraiva, 1995. p. 69.
Estados. Vale dizer que os Estados começaram a ser plenos em suas atividades internas não partilhando as decisões com os demais.

A busca pela ampliação e fortificação de suas fronteiras, nos dizeres de Christopher W. Morris:

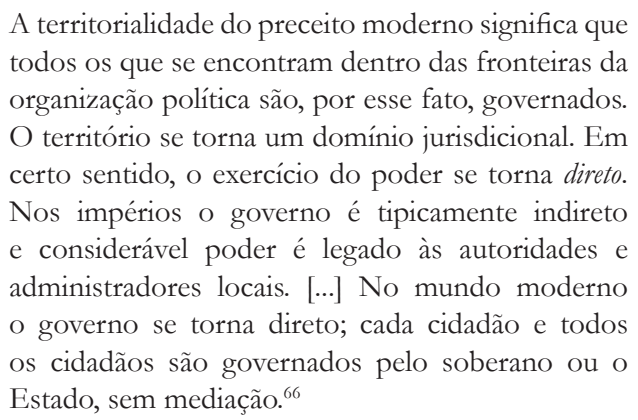

Esse processou fortificou os Estados e permitiu a seus governantes acumularem poder. De tal sorte que os Estados ganharam tamanha importância, que seus governantes acharam-se acima dos demais a ponto de criar uma expansão desenfreada e deflagrar uma guerra entre eles, como forma de determinar e quantificar a força de um eventual protagonista.

\section{Como afirma John G. Stoessinger:}

\begin{abstract}
Nosso mundo se compõe de mais de uma centena de unidades políticas chamadas nações-estado. Quase não há lugar algum neste planeta que alguma nação-estado não considere propriedade sua. Há apenas um século, o mundo ainda tinha muitas fronteiras e terras que permaneciam sem dono. Em nosso tempo, porém, o homem não pode mais escapar ao sistema de nações-estado - a ao ser que emigre para as relegadas zonas polares ou para as estrelas. ${ }^{67}$
\end{abstract}

O problema é que a humanidade não suportou essa disputa insana por poder e os Estados perceberam, ainda que tardiamente, que não é possível existir Estado sem o povo. Logo, após a Segunda Guerra Mundial, ou se limitava o jogo do poder para, assim, se defender o humano, ou uma nova guerra, novos derramamentos de sangue poderiam ocorrer, inclusive com a própria extinção da raça humana. ${ }^{68}$

66 MORRIS, Christopher W. Um ensaio sobre o estado moderno. Tradução Sylmara Beletti. São Paulo: Landy, 2005. p. 66 e 67.

67 STOESSINGER, John G. O poder das naçoes: a política internacional de nosso tempo. Tradução Jamir Martins. São Paulo: Cultrix, 1978. p. 22.

68 "Todos experimentam hoje e todos falam de grande crise dentro da qual vivemos, se bem sabermos as curvas que descreverá. A sucessão de guerras, cada vez mais próximas, seguidas do rápido destroçamento de algumas instituições, - que se criam permanentes - faz de interesse imediato e capital o problema de hoje. As próprias 
E, portanto, a solução encontrada foi criar uma entidade que estivesse em nível hierárquico superior aos dos Estados, uma entidade supranacional, que fosse plena em relação aos demais, para que não houvesse uma disputa, mas sim um consenso. Nascia, assim, a Organização das Nações Unidas. ${ }^{69}$

Além de toda a desgraça e banalização da vida humana as guerras trouxeram outro prejuízo para os Estados: no nível externo/internacional sua soberania, agora, seria limitada na questão dos direitos do ser humano.

\section{A globalização e o QUestionamento acer- CA DA SOBERANIA}

Após toda essa incursão histórica acerca do Estado, primeiramente, e depois, acerca da soberania, estamos aptos a tratar do tema central: a neutralidade.

Não foi apenas com a criação da Organização das Nações Unidas que a soberania dos Estados ficou em xeque, pois outros organismos foram criados, como a Organização Mundial do Comércio, a Organização Internacional do Trabalho e, mais recentemente, o Tribunal Penal Internacional.

Todos esses organismos limitaram, de alguma forma ou aspecto, a soberania dos Estados. Contudo, nada

populações que só veem o lado material (os edifícios, as cidades, as estradas milenares ou recentes), param hoje diante de ruínas nunca vistas. O espírito destrutivo, na sua faina diabólica, desperta-as com o estourar dos bombardeios e o avançar dos tanques". MIRANDA, Pontes de. Democracia, liberdade, igualdade: os três caminhos. Campinas: Bookseller, 2002, p. 27.

69 As Nações Unidas representam o mais ambicioso experimento relativo ao estabelecimento da ordem política no mundo. Num sentido realmente básico, sua concepção se enraíza no passado. Seu edifício foi erigido em tempos de guerra, durante um período de esforço conjunto para derrotar as potências do Eixo. A Organização devia ser criada “[...] para aniquilar, na fonte, outro Hitler, antes que ele se tornasse grande demais. As nações deviam ser 'unidas' contra esse tipo de criminoso. Nesse sentido, a ONU tencionava evitar outra Guerra Mundial como a Segunda, tal como a Liga das Nações, antes, tinha sido criada para prevenir outra guerra mundial como a primeira. [...]. A rocha sobre a qual a ONU se firmaria era a unidade das Grandes Potências, que assumiriam entre si a responsabilidade pela paz e pela ordem mundial. [...] Para capacitar-se a operar a implementação de seus fins, a Organização das Nações Unidas foi dotada de seis órgãos principais. A ambiciosas tarefa de promover a segurança coletiva foi legada ao Conselho de Segurança. $\mathrm{Na}$ fiúza de que a paz era indivisível e de que os Cinco Grandes - Estados Unidos, União Soviética, Grã-Bretanha, França e China - pudessem estabelecer unanimidade entre si, o Conselho de Segurança deveria ser o grande guardião internacional da paz". STOESSINGER, John G. O poder das nações: a política internacional de nosso tempo. Tradução Jamir Martins. São Paulo: Cultrix, 1978. p. 386 - 387. foi mais paradigmático acerca da limitação da soberania do que a globalização e o desenvolvimento dos blocos econômicos.

A globalização ${ }^{70}$ propiciou a queda das fronteiras, algo tão ferrenhamente defendido até 1914, pois, com o livre-comércio, a livre circulação dos povos dentro dos Estados-parte dos blocos econômicos se criava outro conceito de soberania: a soberania dos blocos econômicos, ${ }^{71} \operatorname{logo}$, supranacional, porém distinta da soberania supranacional da ONU, do TPI e de outros. ${ }^{72}$

\section{Para Shankar Vedantam:}

$\mathrm{Na}$ medida em que Estados-nações se tornavam cada vez mais poderosos na segunda metade do século XX, constituições, judiciários e o sufrágio universal forneceram meios mais pacíficos para efetuar mudanças sociais, e o terrorismo passou de uma forma de violência patrocinada pelo Estado a

70 Globalização é, certamente, uma expressão ambígua e vaga. De um lado, admite sentidos conceituais distintos, de outro, aponta para distintos objetos. $\mathrm{Na}$ sua vagueza, refere-se ora a um entrelaçamento das economias nacionais em planos mundiais, ora para formas extensas de comunicação, ora para uma interpretação cultural etc. Na sua ambiguidade, ora revela a simultaneidade in praesentia dos eventos, ora uma generalização dos sentidos prevalecentes, inaugurando uma forma cultural diferente. Samuelson, em artigo publicado em periódicos norte-americanos, vê no encurtamento das distâncias o marco decisivo e inicial da globalização. FERRAZ JÚNIOR, Tercio Sampaio. Direito constitucional: liberdade de fumar, privacidade, estado, direitos humanos e outros temas. São Paulo: Manole, 2007. p. 540.

71 Esta é supranacional, porém, ao contrário da soberania das organizações internacional como Organização das Nações Unidas ou do Tribunal Penal Internacional que possuem soberania que limita parcialmente a soberania dos Estados, a soberania do bloco econômico confere soberania plena, nos moldes de outrora: independência é ilimitada e incondicional em relação aos outros blocos econômicos.

72 Desde o princípio da história, os seres humanos sofreram transformações. E, na medida em que sofriam essas transformações, resistiam a elas. Individualmente ou em grupos, as pessoas resistem a mudanças quando as vivenciam como ameaça, tanto às suas adaptações internas quanto às externas, aos seus ambientes e às suas vidas em geral. A globalização - um tópico bastante discutido nos últimos anos e um agente de mudança acompanhado de grande resistência - é um conceito difícil de descrever. Para o indivíduo, significa desenvolver um tipo de universalidade e um tipo de cidadania mundial. Em uma escala mais prática, o conceito de globalização, hoje, refere-se geralmente às normas culturais, econômicas e políticas da América do Norte e da Europa ocidental que se infiltram em outras populações por todo o globo terrestre. Enquanto no passado houve muitos grupos dominantes - como os Impérios Romano, Bizantino e Islâmico - que também influenciaram profundamente as pessoas que viviam em áreas vizinhas, hoje, por causa da tecnologia avançada, a "globalização" está mais generalizada. ÇEVIK, Abdülkadir. Globalização e identidade. In: VARVIN, Sverre; VOLKAN, Vamik D. (Orgs.). Violência ou diálogo?: reflexões psicanalíticas sobre terror e terrorismo. Tradução Tânia Mara Zalcberg. São Paulo: Perspectiva, 2008. p. 79. 
técnica favorita de grupos subnacionais. Assim, o terrorismo tem sido descrito como 'uma estratégica do fraco contra o forte' - em que nações avançadas com exércitos e forças aéreas não precisam recorrer à criação sistemática do medo para atingir seus fins. $^{73}$

Assim, o que se vê é a mudança do conceito de Estado-nação, como demonstra Anthony D. Smith: ${ }^{74}$

\begin{abstract}
Se queremos dizer com o termo "Estado-nação" que as fronteiras do território do Estado e de uma comunidade étnica homogênea são coextensivas, e que todos os habitantes de um Estado possuem uma cultura idêntica, não conseguiremos reunir mais do que cerca de 10 por cento dos Estados hoje existentes como candidatos ao título de "Estadonação". ${ }^{75}$
\end{abstract}

Com a instituição do Estado Democrático de Direito e o compromisso dos Estados em combates às mazelas perpetradas contra a humanidade, o que se viu desde a metade do século XX foi um esforço coletivo e globalizado no sentido de a soberania ainda ser plena, porém que o ser humano e, mais ainda, a defesa da dignidade da pessoa humana, seja o mote fundamental, e com ela não haveria possibilidade de questionamentos ou violações, nem em nome da defesa da soberania deste ou daquele Estado.

73 ÇEVIK, Abdülkadir. Globalização e identidade. In: VARVIN, Sverre; VOLKAN, Vamik D. (Orgs.). Violência ou diálogo?: reflexões psicanalíticas sobre terror e terrorismo. Tradução Tânia Mara Zalcberg. São Paulo: Perspectiva, 2008. p. 11.

74 Deixando de lado as minorias insignificantes, nós talvez consigamos incluir alguns poucos Estados além de Portugal, Grécia, polônia e Somália; Holanda, Dinamarca e as duas Alemanhas têm pequenas minorias, mas, se deixarmos de lado os trabalhadores imigrantes, também são hoje bastante homogêneos. Em outros Estados - Suécia, Noruega e Finlândia, por exemplo - as minorias dos lapões e dos carelianos não ameaçam, talvez por não poderem, a unidade cultural do Estado. Mesmo assim, ainda resta um número bastante considerável, talvez mais da metade, com sérias divisões étnicas que podem transformar em antagonismo, e em outro grande grupo, talvez mais de um quarto do total, onde a cultura ou comunidade dominante deve apaziguar as reivindicações de etnias "periféricas", como na Grã-Bretanha, França e Canadá, Romênia e Bulgária. Nos 50 por cento com diferenças culturais profundas, nem sempre tem sido possível conter as reivindicações antagônicas ou atender às exigências de comunidades rivais. $\mathrm{Na}$ Índia, Sri Lanka, Birmânia, nas Filipinas, Indonésia, Laos, Irã, Iraque, Turquia, Chipre, Espanha, Iugoslávia, Córsega (França), Irlanda, Chade, Nigéria, Camarões, Zaire, Zâmbia, Zimbábue, África do Sul, Uganda, Quênia, Sudão e Etiópia, essas divisões já explodiram em violência aberta e mesmo em guerra posteriormente a 1914. SMITH, Anthony D. Criação do estado e construção da nação. In: HALL, John A. (Org.). Os estados na bistória. Tradução Paulo Vaz, Almir Nascimento e Roberto Brandão. Rio de Janeiro: Imago, 1992. p. 335.

75 SMITH, Anthony D. Criação do estado e construção da nação. In: HALL, John A. (Org.). Os estados na história. Tradução Paulo Vaz, Almir Nascimento e Roberto Brandão. Rio de Janeiro: Imago, 1992. p. 334 e 335.
Os Estados, então, manteriam de lado o anseio deliberado pelo poder, pela conquista e pela demonstração de força para, enfim, valorizar o ser humano.

O resultado é a assunção de uma posição neutra, isto é, a Organização das Nações Unidas criou o sistema de Direitos Humanos e uma série de instrumentos protetivos das liberdades e os Estados, em contrapartida, trariam para o âmbito interno, em que são soberanos, os mandamentos instaurados no plano externo.

Com isso, as Constituições nacionais tiveram de ser modificadas e um novo conceito se instituía: a defesa e proteção dos direitos fundamentais, por meio de um Estado Democrático de Direito cuja principal característica seria a neutralidade.

Assim, no plano religioso, mote desta obra, o Estado se declarava laico, isto é, não adotava, portanto, uma religião de forma oficial.

\section{A NeUtRALIDADE DOS ESTADOS X SObERANIA EXTERNA E INTERNA}

Com a edificação de um primado de Direitos $\mathrm{Hu}$ manos, os Estados laicos adquiriram posição de neutralidade, isto é, não interfeririam no cenário externo no tocante à intolerância e o que prevaleceria seria o entendimento protecional estabelecido pela Organização das Nações Unidas. Já no âmbito interno, os Estados laicos deveriam recepcionar a normatização internacional em seu ordenamento jurídico para efetivar as liberdades dentro do Estado Democrático de Direito.

No plano teórico, tudo funciona perfeitamente, porém, o que se viu no princípio do século XXI foi uma realidade cindida do plano teórico. Especialmente em decorrência dos atentados terroristas de 11 de Setembro de 2001, os Estados laicos adotaram posturas ambíguas em relação à tolerância religiosa e uma série de medidas foram adotadas em contrariedade ao primado da neutralidade.

Os Estados laicos se mostraram intolerantes e a postura neutra de outrora ganha contornos de intolerância à medida que alguma ameaça se manifesta no plano internacional. Assim, o Estado Democrático de Direito é mais ou menos laico na exata proporção de sua intolerância. 
A efetivação da proteção do ser humano e da conseguinte efetivação das liberdades e do exercício da tolerância perpassa definitivamente pela laicidade/tolerância do Estado Democrático de Direito. Não há como ignorar leis que segregam direitos religiosos, limitam e restringem as liberdades das minorias religiosas.

Se os Estados pregam e preconizam a tolerância, não podem, na prática, ser intolerantes. Porém, é exatamente o que acontece com a França,${ }^{76}$ com a Turquia, ${ }^{77}$ com a Austrália ${ }^{78}$ com a Dinamarca ${ }^{79}$ e com os Estados Unidos da América, ${ }^{80}$ apenas para citar alguns Estados laicos.

A neutralidade inexiste em matéria religiosa. Um Estado Democrático de Direito não pode criar lei que favorece esta ou aquela religião, seu primado fundamental é se manter neutro, seja no cenário externo ou no interno. Porém, sob o mote da segurança a neutralidade é ignorada.

Os Estados Unidos da América, um dos membros do Conselho de Segurança da Organização das Nações Unidas, portanto, um dos Estados responsáveis pela promoção da paz e da tolerância entre os Estados-nações em resposta aos atentados terroristas de 11 de Setembro de 2001, deflagraram uma guerra contra o terror, ao partir para um conflito bélico, primeiro contra o Afeganistão e, depois, contra o Iraque.

Um dos Estados que deveria lutar contra a guerra e estabelecer os Direitos Humanos e a dignidade da pessoa humana foi o primeiro a abandonar a neutralidade ao adotar postura extremamente intolerante no que tange à religião, ao instituir um centro de torturas contra pessoas, em sua maioria islâmicas, localizado na Baia de Guantánamo.

$\mathrm{Na}$ Baia de Guantánamo não existem direitos e garantias e muito menos tolerância religiosa. A posição é salvaguardar a segurança do Estado.

76 Aliás, sobre a questão francesa, existem, ainda, alguns agravantes de intolerância com a introdução da Lei $n^{\circ} 228 / 2004$, que proíbe o uso de sinais e vestimentas religiosas ostensivas nas escolas públicas de primeiro e segundo graus em todo o território francês.

77 Proibição do uso do véu islâmico nos colégios públicos.

78 A autorização de a polícia obrigar a mulher a tirar sua burca sem mais justificativas.

79 Se uma pessoa se declarar muçulmana no controle de imigração ao preencher o formulário de ingresso no País, sua entrada será sumariamente rejeitada.

80 A caça às bruxas com o vilipêndio de direitos por meio da Baia de Guantánamo, na qual um incontável número de muçulmanos foram levados de seus lares para serem torturados com o intuito de indicarem o paradeiro dos líderes de células terroristas.
E como fica a neutralidade? A Organização das Nações Unidas? O Sistema de Direitos Humanos? A resposta é simples: a soberania interna, como vimos, é intocável. E como os Estados Unidos da América não ratificaram o Estatuto de Roma que institui o Tribunal Penal Internacional, não há como se julgar crimes contra a humanidade cometidos por aquele Estado.

Na mesma esteira temos uma série de medidas intolerantes praticadas pelos Estados laicos que abandonaram a neutralidade para impingir a intolerância religiosa no cenário interno, portanto, no qual detêm soberania plena.

De tal sorte que a neutralidade do Estado laico se encontra prejudicada por conta de um instrumento que os organismos internacionais ainda não conseguiram encontrar, ou seja, um caminho para viabilizar uma igualdade e uma tolerância: a soberania interna dos Estados.

O limite dos organismos internacionais é o cenário externo. Ainda não é possível forçar um Estado a ser mais democrático, a respeitar a neutralidade e a garantir as liberdades em seu âmbito interno, pois a soberania ainda é inquestionável.

Por isso, o entrave para a questão da intolerância religiosa passa diretamente pela soberania interna do Estado Democrático de Direito. Enquanto os próprios Estados não implementarem modificações em seu cenário interno, o âmbito externo ainda permanece em compasso de espera.

O efeito prático da adoção de medidas de tolerância e, de assunção de liberdades não corresponde ao plano teórico por puro e completo desinteresse dos próprios Estados que se dizem democráticos e laicos.

De fato, os Estados ainda convivem com o mesmo problema que os corrompeu e deflagrou as duas Grandes Guerras Mundiais: a busca por poder. ${ }^{81}$

Para Ives Gandra da Silva Martins:

O homem, que tem sua própria individualidade, mas que só sobrevive coletivamente, não dirige no Estado Moderno, como não dirigia, nas estruturas políticas passadas, seu destino, sendo este definido

81 Com efeito, o jogo político não deixa de lado qualquer Estado, por insignificante que seja, os afrontamentos mais remotos se refletem em toda parte, bem como os meios de guerra não deixam em segurança ponto algum do planeta. FERREIRA FILHO, Manoel Gonçalves. Especulações sobre o futuro do Estado. In: MARTINS, Ives Gandra da Silva (Coord.). O estado do futuro. São Paulo: Pioneira, 1998. p. 103. 
por aqueles que assumem o poder, legitimamente ou não, e que, na esmagadora maioria das vezes, ambicionam apenas ter o poder pelo poder, inclusive nas mais avançadas democracias do mundo. ${ }^{82}$

A solução para a intolerância dos Estados laicos e o regresso à neutralidade perpassa pela superação do Estado-nação e seus interesses internos. Enquanto os Estados não efetivarem sua postura neutra no que tange à tolerância religiosa, os conflitos permanecerão.

Como salienta Celso Ribeiro Bastos e Samantha Meyer-Pflug:

[...] o Estado deve manter-se absolutamente neutro. Isso implica no fato de ele não poder discriminar entre as diversas igrejas e templos existentes, quer para beneficiá-los, quer para prejudicá-los. A separação entre Estado e religião vem prevista no inc. I do art. 19 da Constituição de 1988, que declara ser vedado à União, aos Estados, ao Distrito Federal e aos Municípios estabelecer cultos religiosos ou igrejas, subvencioná-los, embaraçar-lhes o funcionamento ou manter com eles ou seus representantes relações de dependência ou aliança, ressalvada, na forma da lei, a colaboração de interesse público. ${ }^{83}$

A paz tão almejada ainda não se efetivará enquanto o cenário de "neutralidade" dos Estados Democráticos de Direito não for convertida para uma neutralidade efetiva e a palavra "laico" seja levada a cabo.

No modelo que temos hoje, com a laicidade refém da intolerância do próprio Estado, inviabiliza-se a neutralidade e a assunção das liberdades, tanto no plano interno quanto no cenário internacional.

\section{Considerações finais}

O modelo estatal parece ter alcançado uma incompatibilidade com o que se busca em termos de liberdade, igualdade e fraternidade na sociedade global do século XXI, pois o modelo de busca pelo poder ainda persiste e a mão controladora do Estado ainda obstaculiza a assunção das liberdades no cenário interno e, por conseguinte, promove a inaplicabilidade do próprio sistema de tolerâncias no cenário internacional.

82 MARTINS, Ives Gandra da Silva. O Estado do futuro. In: MARTINS, Ives Gandra da Silva (Coord.). O estado do futuro. São Paulo: Pioneira, 1998. p. 17 e 18.

83 BASTOS, Celso Ribeiro; MEYER-PFLUG, Samantha. Do direito fundamental à liberdade de consciência e de crença. Revista de Direito Constitucional e Internacional, São Paulo, n. 36, p. jul./set. 2001.
Para que a neutralidade seja efetiva no plano internacional, é necessário que os Estados modifiquem sua postura intolerante no cenário interno em que são soberanos. Assim, ainda não há que se falar em um sistema plurinacional que convive de forma harmônica em busca da paz se os sistemas nacionais ainda buscam alternativas para, justamente, caminhar na direção oposta da paz.

O Estado Democrático de Direito se mostra plural, em sua maioria com uma Constituição aberta, com a possibilidade de harmonia entre os povos, o respeito às diferenças e a tolerância como mote fundamental desse Estado. Porém, o que se vê nas Constituições democráticas não se aplica na realidade desses mesmos Estados. Assim, a humanidade vive o entrave de buscar sua liberdade e depender do Estado para concedê-las, porém, na prática, o primeiro não se vê satisfeito por ineficiência do segundo.

É preciso se efetivar o modelo teórico, uma vez que todos os primados, todas as liberdades pretendidas já estão estipuladas e estabelecidas, porém, ainda lhes falta efetivação. E, sobre isso, o problema perpassa pela carência da efetiva neutralidade do Estado laico.

Toda a apresentação em torno do que vem a ser Estado e como que esse adquiriu o contorno hoje conhecido de Estado-nação foi necessário para poder mostrar que o que se pretende, enquanto sociedade plural, não corresponde à realidade desse mesmo Estado-nação e, este, sim, representa o problema moderno a ser saneado para desanuviar o sentimento de uma nova guerra, pois, a cada dia temos a impressão de que uma guerra mundial, uma vez mais se aproxima. Uma guerra ou, no mínimo, uma bipolarização entre o Ocidente e o Oriente no que tange à questão religiosa. $\mathrm{E}$, assim, qualquer passo democrático não calculado pode eclodir uma beligerância mundial.

Essa visão parece ser uma antecipação do cataclisma e o suprassumo do pessimismo; todavia, foi com esse pensamento, o de se evitar a destruição do ser humano que se desenvolveu e se criou a Organização das Nações Unidas e seu primado de Direitos Humanos. No entanto, transcorridos pouco mais de 60 anos, o que se vê é um comprometimento parcial, com enorme relutância em efetivar o que se assume no plano internacional no âmbito interno.

A humanidade ainda padece com essa relutância dos Estados. A neutralidade efetiva é o caminho a ser pavi- 
mentado para a consolidação do que busca a Organização das Nações Unidas: a tolerância religiosa e a liberdade para pensar, agir, acreditar e expressar sua fé. Que não seja preciso mais uma guerra para os governantes perceberem que a disputa por poder é, de fato, o maior obstáculo a ser superado.

\section{REFERÊNCIAS}

BASTOS, Celso Ribeiro; MEYER-PFLUG, Samantha. Do direito fundamental à liberdade de consciência e de crença. Revista de Direito Constitucional e Internacional, São Paulo, n. 36, jul./set. 2001.

BERARDO, Telma. Soberania e direitos humanos: reconceituação com base na dignidade da pessoa humana. 2003. f. Tese (Mestrado na área de concentração de Direito Constitucional)_Pontifícia Universidade Católica, São Paulo, 2003.

BOBBIO, Norberto. O Terceiro ausente. Tradução Daniela Versiani. Barueri: Manole, 2009.

BOBBITT, Philip. A guerra e a paz na história moderna: o impacto dos grandes conflitos e da política na formação das nações. Tradução Cristiana Serra. Rio de Janeiro: Campus, 2003.

BONAVIDES, Paulo. Teoria geral do estado. 8. ed. São Paulo: Malheiros, 2010.

CASSAMANO, Marco Aurélio. Política e religião: o estado laico e a liberdade religiosa à luz do constitucionalismo brasileiro. 2006. f. Tese (Doutorado na área de concentração de Direito, Estado e Sociedade)—Pontifícia Universidade Católica de São Paulo, São Paulo, 2006.

ÇEVIK, Abdülkadir. Globalização e identidade. In: VARVIN, Sverre; VOLKAN, Vamik D. (Orgs.). Violência on diálogo?: reflexões psicanalíticas sobre terror e terrorismo. Tradução Tânia Mara Zalcberg. São Paulo: Perspectiva, 2008.

COMPARATO, Fábio Konder. A afirmação bistórica dos direitos humanos. 3. ed. São Paulo: Saraiva, 2003.

DALLARI, Dalmo de Abreu. Elementos de teoria geral do estado. 19. ed. São Paulo: Saraiva, 1995.

DALLARI, Dalmo de Abreu. In: VIEIRA, Oscar Vilhena (Coord.). Direitos bumanos, estados de direito e a construção da paz: São Paulo: Quartier Latin, 2005.
DICIONÁRIO do pensamento social do século XX. Rio de Janeiro: Jorge Zahar, 1996.

DICIONÁRIO Houaiss da língua portuguesa. Rio de Janeiro: Objetiva, 2009.

DOMINGOS, Marília de Franceschi Neto. Escola e laicidade: o modelo francês. Interações: cultura e comunidade, Uberlândia, v. 3, n. 4, p. 153-170, 2008.

EMILIANO BARREIROS, Lucas. El derecho internacional contemporáneo y el problema de la soberanía: un intento de reconciliación. In: PINTO, Mónica. (Org.). Las fuentes del derecho internacional en la era de la globalización. Buenos Aires: Eudeba, 2009.

FERRAZ JÚNIOR, Tercio Sampaio. Direito constitucional: liberdade de fumar, privacidade, estado, direitos humanos e outros temas. São Paulo: Manole, 2007.

FERREIRA FILHO, Manoel Gonçalves. Especulações sobre o futuro do Estado. In: MARTINS, Ives Gandra da Silva (Coord.). O estado do futuro. São Paulo: Pioneira, 1998.

FRANÇA, R. Limongi. Enciclopédia Saraiva de direito. São Paulo: Saraiva, 1977. v. 53.

GIDDENS, Anthony. O estado-nação e a violência. Tradução Beatriz Guimarães. São Paulo: Universidade de São Paulo, 2001.

GRANDE enciclopédia larousse cultural. São Paulo: Nova Cultural, 1998. v. 12.

HINSLEY, F. H. El concepto de soberania. Tradução Fernando Morera e Angel Alandí. Barcelona: Labor, 1972.

HOBBES, Thomas. Leviatã. São Paulo: Nova Cultural, 1999. (Os Pensadores).

HOBSBAWM, Eric. A era das revolucões 1789-1848. Tradução Maria Tereza Teixeira e Marcos Pimentel. 25. ed. São Paulo: Paz e Terra, 2010.

HOBSBAWM, Eric. A era dos impérios 1875-1914. Tradução Sieni Maria Campos e Yolanda Steidel de Toledo. 13. ed. São Paulo: Paz e Terra, 2011.

HOBSBAWM, Eric. Era dos extremos. O breve século XX 1914-1991. Tradução Marcos Santarrita. 2. ed. São Paulo: Companhia das Letras, 1995.

HOBSBAWM, Eric. Globalização, democracia e terrorismo. Tradução José Viegas. São Paulo: Companhia das Letras, 2007. 
HOBSBAWM, Eric. J. A era do Capital 1848-1875. Tradução Luciano Costa Neto. 15. ed. São Paulo: Paz e Terra, 2011.

HOBSBAWM, Eric. Nações e nacionalismo desde 1780. Tradução Maria Celia Paoli e Anna Maria Quirino. São Paulo: Paz e Terra, 2011.

MARTINS, Ives Gandra da Silva. O Estado do futuro. In: MARTINS, Ives Gandra da Silva (Coord.). O estado do futuro. São Paulo: Pioneira, 1998.

MIRANDA, Pontes de. Democracia, liberdade, igualdade: os três caminhos. Campinas: Bookseller, 2002.

MORRIS, Christopher W. Um ensaio sobre o estado moderno. Tradução Sylmara Beletti. São Paulo: Landy, 2005.

SILVA, De Plácido e. Vocabulário jurídico. 28. ed. Rio de Janeiro: Forense, 2010.
SILVA, José da. Liberdade, realidade política e eficácia da constituição. In: ROCHA, Maria Elizabeth Guimarães Teixeira; MEYER-PFLUG, Samantha Ribeiro. Lições de direito constitucional em homenagem ao professor Jorge Miranda. Rio de Janeiro: Forense, 2008.

SMITH, Anthony D. Criação do estado e construção da nação. In: HALL, John A. (Org.). Os estados na história. Tradução Paulo Vaz, Almir Nascimento e Roberto Brandão. Rio de Janeiro: Imago, 1992.

STOESSINGER, John G. O poder das nações: a política internacional de nosso tempo. Tradução Jamir Martins. São Paulo: Cultrix, 1978.

SUNDFELD, Carlos Ari. Fundamentos de direito público. 4. ed. São Paulo: Malheiros, 1997. 
Para publicar na Revista de Direito Internacional, acesse o endereço eletrônico www.rdi.uniceub.br ou www.brazilianjournal.org.

Observe as normas de publicação, para facilitar e agilizar o trabalho de edição. 